\title{
Technology indicators referring tot education and labour
}

Citation for published version (APA):

de Grip, A., \& Nusselder, W. J. (1989). Technology indicators referring tot education and labour. Researchcentrum voor Onderwijs en Arbeidsmarkt, Faculteit der Economische Wetenschappen. ROA Reports No. 4E https://doi.org/10.26481/umarep.198904E

Document status and date:

Published: 01/01/1989

DOI:

10.26481/umarep.198904E

Document Version:

Publisher's PDF, also known as Version of record

\section{Please check the document version of this publication:}

- A submitted manuscript is the version of the article upon submission and before peer-review. There can be important differences between the submitted version and the official published version of record.

People interested in the research are advised to contact the author for the final version of the publication, or visit the DOI to the publisher's website.

- The final author version and the galley proof are versions of the publication after peer review.

- The final published version features the final layout of the paper including the volume, issue and page numbers.

Link to publication

\footnotetext{
General rights rights.

- You may freely distribute the URL identifying the publication in the public portal. please follow below link for the End User Agreement:

www.umlib.nl/taverne-license

Take down policy

If you believe that this document breaches copyright please contact us at:

repository@maastrichtuniversity.nl

providing details and we will investigate your claim.
}

Copyright and moral rights for the publications made accessible in the public portal are retained by the authors and/or other copyright owners and it is a condition of accessing publications that users recognise and abide by the legal requirements associated with these

- Users may download and print one copy of any publication from the public portal for the purpose of private study or research.

- You may not further distribute the material or use it for any profit-making activity or commercial gain

If the publication is distributed under the terms of Article $25 \mathrm{fa}$ of the Dutch Copyright Act, indicated by the "Taverne" license above, 


\title{
TECHNOLOGY INDICATORS REFERRING TO EDUCATION AND LABOUR \\ ROA-R-1989/4E
}

\author{
A. de Grip \\ W.J. Nusselder
}

RESEARCH CENTRE FOR EDUCATION AND LABOUR MARKET

Faculty of Economic Sciences

Rijksuniversiteit Limburg

Maastricht, October 1989 
CIP-GEGEVENS KONINKLIJKE BIBLIOTHEEK, DEN HAAG

Grip, A. de

Technology indicators referring to education and labour /

A. de Grip, W.J. Nusselder ; [trans1. from the Dutch]. -

Maastricht : Research Centre for Education and Labour Market, Faculty of Economic Sciences, University of Limburg. - (Report / Research Centre for Education and Labour Market ; 1989/4E) Vert. van: Technologie-indicatoren met betrekking tot scholing en arbeid. - Maastricht : ROA, 1989. - Met 1it. opg.

ISBN 90-5321-026-1

SISO 318.7 UDC $37: 331.5$

Trefw.: onderwijs en arbeidsmarkt 
1. INTRODUCTION 1

2. TECHNOLOGY INDICATORS 4

2.1. Initial education 4

2.1.1. Educational expenditure per student 4

2.1.2. Share of vocational education in total regular education $\quad 7$

2.1.3. Dual education 8

2.1.4. Share of graduates with a technical education in the total number of graduates of higher education 9

2.1.5. Computers in primary and secondary education 10

2.2. Labour force and schoolleavers 13

2.2.1. Average level of education of schoolleavers and the potential labour force 13

2.2.2. Share of technically educated in the total number of schoolleavers and in the potential labour force 18

2.2.3. Share of technically educated in management occupations 22

2.3. Need for training 26

2.3.1. Tensions in the labour-market situation of technically skilled people 26

2.3.2. Share of over thirties persons in the economically active population 26

2.4. Training efforts 28

2.4.1. Training expenditure 28

2.4.2. Proportion of the potential labour force participating in training 31

2.4.3. Training agreements in Collective Employment Contracts

3. EVALUATION 38

3.1. Summarising review 38

3.2. Suitability test 38 
In the framework of plans to create a Data Bank of Technology Indicators, the Directorate for Technology Policy of the Ministry of Economic Affairs comissioned the Researchcentre for Education and Labour Market to develop technology indicators referring to education and labour. This report describes the research undertaken to that effect. An aspect to be investigated in particular was how far the indicators developed would permit comparisons with other countries. The research was carried out by $\operatorname{Dr} A_{\text {. de }}$ Grip (project leader) and Drs W.J. Nusselder, with the assistance of Drs G.W.M. Ramaekers and J.J. Smorenburg. 


\section{INTRODUCTION}

In its proposal for a data bank of technology indicators for general technology policy: MEASUREMENT ('Voorstel voor een gegevensbank van Technologie-indicatoren voor A.T.B.: METING') the Ministry of Economic Affairs presents several technology indicators. By means of these indicators the Ministry intends to set up a data bank which could serve as a source of quantitative information for a well-founded government policy in the area of technology. This report focuses on technology indicators referring to education and labour that could be included in this data bank.

Technological developments on the one hand and education and labour on the other have a relation of mutual influence. The level of education of the labour force is an important determinant of a nation's Research \& Development capacities, and thus influences a nation's innovative capacity. The ensuing technological developments in turn make a tremendous impact on contemporary society. The growth of the national economy and the shifts in economic structure come instantly to mind, but the effects of technological progress on the volume and structure of employment, the contents of jobs, the associated educational requirements and the resulting nature and level of education are equally important aspects. Besides, not only the nature, but also the pace of changes ensuing from technological progress is important. Indeed, the pace at which innovations are introduced may create new uncertainties and lay heavy claims on individuals or on society at large. In that connection, the educational level of the labour force is an important determinant of the diffusion of technological development. An improved production technique alone is no guarantee for greater productivity. Certain marginal conditions will have to be fulfilled first, for instance regarding the training of staff 1 .

Having established that the level of education of the labour force is important for society's innovative potential, that technological advance carries uncertainties, and that the effects of innovation are many and manifold, we understand how crucial a good insight into the changes and their consequences is to a successful policy. The available societal and scientific infrastructure for technological advance should be exploited to

1. By education is understood not only initial education, but also the reeducation or re-training of employed people, jobseekers and others who have already left the system of initial education. 
the full. We have already seen that the nature and level of education of the (professional) population are both determinants of, and significant conditions for, technological innovations. Skilled management, able to spot new technological openings, is another requirement. With the rapid progress of technology all knowledge tends to become obsolete very rapidly, so that permanent education grows more and more important.

The MEASUREMENT proposal referred to above suggests a classification of indicators similar to that of the indicator bank of the science and Technology Agency in Japan. Six types of indicators are distinguished:

1. Indicators which can be considered indicative of the societal infrastructure for technological developments.

2. Indicators which can be considered indicative of the scientific and technological infrastructure, and in particular of the Research and Development (R\&D) activities performed.

3. Indicators which are indicative of the R\&D infrastructure and intended to measure R\&D activities.

4. Indicators which are indicative of of R\&D results.

5. Indicators intended to measure the economic impact of R\&D.

6. Indicators representing the indirect impacts of science and technology on society and their acceptance by society.

Indicators referring to education, training and labour can be regarded as measures of, in particular, the scientific and technological infrastructure. Remarkably, the Japanese Science and Technology Agency recognises only the relevance of the social infrastructure (1) and the scientific and technological infrastructures (2) to the generation of R\&D activities, and ignores completely how far the associated indicators can be a measure of the diffusion of technological developments. In the present report, which aims to do justice to both aspects, a further distinction is made between innovation and diffusion potentials.

The MEASUREMENT paper mentions some criteria for the indicators to satisfy. First, they must serve the various aspects of General Technology Policy. Second, they must be feasible to construct. Third, input and output indicators should be balanced as well as possible. Fourth, some of the indicators must give an insight into the social aspects of technological progress. Fifth, the indicators should be composable for other countries as well, to permit international comparisons. And last, the sources from which 
the indicators are computed must give some assurance of continuity.

In particular the last two criteria have been kept in mind in the writing of this report. In an attempt to develop internationally comparable indicators we have first of all scanned the data files of international organisations such as OECD, European Community, ILO and UNESCO. The harvest being less than expected initially, we proceeded to publications of national statistical offices ${ }^{2}$.

The next chapter presents the indicators finally collected, in the following order. Section 2.1. considers how initial education contributes to the future (social and) scientific and technological infrastructure for technological progress. Section 2.2. presents indicators measuring the present infrastructure for technological developments as far as present among the (potential) labour force. Similar indicators referring to schoolleavers are used to measure the dynamics of the infrastructure for technological progress. Section 2.3 presents indicators measuring the need for training for the relief of present or possible future impediments to the diffusion of technological advance. Section 2.4., finally, gives the indicators measuring present educational efforts made to remove such impediments.

2. To approach the statistical offices of the various countries was beyond the scope of our commission, so we had to content ourselves with consulting the publications available with the (Dutch) CBS. 


\section{TECHNOLOGY INDICATORS}

From data acquired from the Central Planning Office and the Central Bureau for Statistics, some technology indicators have been composed for the Netherlands. As potential international comparability is a major criterion by which to judge these indicators, we have tried to investigate the possibilities to compose indicators for other countries. Thereby we looked to the following countries: France, West Germany, United Kingdom, Austria Sweden, the United States and Japan, For these countries we also actually tried to compose some of these indicators.

\subsection{Initial education}

\subsubsection{Educational expenditure_per student}

The first indicator we have developed refers to total public spending on education per student. This indicator is a measure of a country's scientific and technological infrastructure. It reflects annual investments in human capital for house shortly to enter the labour market, and embodies both the innovative and the diffusion potential.

This indicator can be composed for the Netherlands and the other selected countries. From the annual Unesco publication Unesco Statistical Digest (1983-1987), public educational expenditure per student can be computed for the 1975-1984 period ${ }^{3}$. The Unesco publication represents educational expenditure in national currencies. To make it comparable among countries we have converted all national figures to American dollars (at the 1987 rate of exchange). Table 1 gives a review.

3. There are no more recent data available. 
Table 1. Public educational expenditure per student (x 1,000 1987 US dollars)

\begin{tabular}{lrrrrrrr}
\hline & 1975 & 1980 & 1981 & 1982 & 1983 & 1984 & 1985 \\
\hline France & & & & & & & \\
West Germany & 0,98 & 1,82 & -- & -- & 2,67 & -- & -- \\
United Kingdom & 2,32 & 3,24 & -- & 3,54 & 3,66 & 4,12 & -- \\
Austria & 0,97 & 1,88 & -- & 2,27 & 2,45 & 2,60 & -- \\
Sweden & 1,97 & 3,04 & 3,55 & 3,87 & 4,16 & 4,37 & 4,57 \\
The Netherlands & 2,16 & 4,45 & 4,82 & 5,13 & 5,39 & 5,80 & -- \\
United States & 2,51 & 3,75 & 3,93 & 4,05 & 4,09 & 4,05 & -- \\
Japan & 1,61 & 3,15 & 3,33 & $-\overline{3}$ & -- & 3,86 & -- \\
& 2,46 & 3,80 & 4,06 & 4,07 & 4,07 & 4,22 & -- \\
\hline
\end{tabular}

Source : UNESCO/ROA.

Legend : -- = not available.

The expenditure data can be better interpreted when converted to index figures. The exercise results in two additional indicators. First the index which relates educational expenses in the various countries to a given base year (see table 2). Second, the index relating educational expenditure by student of various countries to the expenditure in the Netherlands in the same year (see table 3 ).

Table 2. Public educational expenditure per student in national currencies $(1980=100)$.

\begin{tabular}{lrrrrrrr}
\hline & 1975 & 1980 & 1981 & 1982 & 1983 & 1984 & 1985 \\
\hline France & 54 & 100 & -- & -- & 146 & -- & -- \\
West Germany & 72 & 100 & -- & 109 & 113 & 127 & -- \\
United Kingdom & 52 & 100 & -- & 121 & 131 & 139 & -- \\
Austria & 65 & 100 & 117 & 127 & 137 & 144 & 151 \\
Sweden & 49 & 100 & 108 & 115 & 121 & 130 & -- \\
The Netherlands & 67 & 100 & 105 & 108 & 109 & 108 & -- \\
United States & 51 & 100 & 106 & -- & -- & 123 & -- \\
Japan & 65 & 100 & 107 & 107 & 107 & 111 & -- \\
& & & & & & & \\
\hline
\end{tabular}

Source : UNESCO/ROA

Legend : $--=$ not available

From table 2, educational expenditure per student appears to have increased in all countries investigated in the first half of the 1980 s, least so in the Netherlands. Only in the Netherlands did educational expenses per student decline in 1984. The analysis should pay heed to the fact that the time series are not deflated, that is to say, they are not corrected for price developments. Part of the observed increase in educational expenditure 
can therefore be attributed to price increases. Proper correction is feasible in principle.

Table 3. Public educational expenditure per student (x 1,000 1987 US dollars) (The Netherlands $=100$ )

\begin{tabular}{lrrrrrrr}
\hline & 1975 & 1980 & 1981 & 1982 & 1983 & 1984 & 1985 \\
\hline France & 39 & 49 & -- & -- & 65 & -- & -- \\
West Germany & 92 & 86 & -- & 87 & 90 & 102 & -- \\
United Kingdom & 39 & 50 & -- & 56 & 60 & 64 & -- \\
Austria & 79 & 81 & 90 & 95 & 102 & 108 & -- \\
Sweden & 86 & 119 & 123 & 127 & 132 & 143 & -- \\
The Netherlands & 100 & 100 & 100 & 100 & 100 & 100 & -- \\
United States & 64 & 84 & 85 & -- & -- & 95 & -- \\
Japan & 98 & 101 & 103 & 101 & 100 & 104 & -- \\
& & & & & & & \\
\hline
\end{tabular}

Source : UNESCO (1984, 1985, 1986, 1987)

Legend: $--=$ not available

Table 3 shows how the Netherlands rank among other countries. The striking fact is that the Netherlands lost their relative lead in the first half of the 1980s. By 1984, the Netherlands had dropped to the category with the lowest educational expenditure per student, together with the United Kingdom and the United States. The table shows up the wide variation in educational expenditure per student among countries. In France and the United Kingdom, the public sector spends a lot less on education, per student, than in the other countries. Admittedly, in France and to a lesser extent in the United Kingdom a tendency to catch up can be observed. Sweden, Japan and Austria on the other hand are marked by high expenditure per student. Remember, however, that the figures refer only to public expenditure, and that different shares of private outlays in total educational expenditure may account for different levels of the indicators among countries. For that reason, an indicator of total educational expenditure (public and private financing) would in principle be preferable. Unfortunately, the relevant information is not available from publications of international organisations.

The Netherlands time series could be extended to 1985 from CBS data, but the 1985 figure thus obtained would not be directly comparable with those in table 3. For that reason it is not presented here. 
2.1.2. Share of vocational education in total regular education

In this section, we present an indicator which represents the share of second- and third-level vocational students and undergraduates 4 in the total number of second- and third-level students and undergraduates. The Statistical Yearbook of Unesco (1983-1987) enables us to split off vocational education. For the computation of the indicator, third-level education (Higher Education) has been entirely counted to vocational education.

The above ratio is indicative notably of the students' openness to technological developments in their later career. The underlying assumption is that people with broad initial vocational schooling tend to be more responsive to innovations than workers who have gained their skill 'on the job' during their professional career and whose theoretical knowledge is apt to be less comprehensive. Thus, this indicator can be regarded as indicative of the scientific and technological infrastructure for the diffusion of technological change. Possibly, a higher share of vocational education can also count as an enhancement of the society's innovative potential.

Table 4. Indicator of the share of vocational students (second and third levels)

\begin{tabular}{lccccccc}
\hline & $\begin{array}{c}1975 \\
\%\end{array}$ & $\begin{array}{c}1980 \\
\%\end{array}$ & $\begin{array}{c}1981 \\
\%\end{array}$ & $\begin{array}{c}1982 \\
\%\end{array}$ & $\begin{array}{c}1983 \\
\%\end{array}$ & $\begin{array}{c}1984 \\
\%\end{array}$ & $\begin{array}{c}1985 \\
\%\end{array}$ \\
\hline Japan & 34 & 32 & 32 & 30 & 30 & 29 & -- \\
Austria & 25 & 33 & 33 & 35 & 37 & 40 & 41 \\
France & 35 & 36 & 36 & 40 & 38 & 39 & 35 \\
West Germany & 32 & 33 & 35 & 37 & 29 & 31 & 32 \\
The Netherlands & 51 & 53 & 53 & 54 & 55 & 55 & -- \\
Sweden & 45 & 45 & 46 & 49 & 51 & 51 & -- \\
United Kingdom & 16 & 18 & 19 & 19 & 20 & 23 & -- \\
& & & & & & & \\
\hline
\end{tabular}

Source : UNESCO/ROA

Legend : -- = not available

Table 4 shows the Netherlands and Sweden to have the highest shares of vocational students, while in the United Kingdom it is very low. In most countries, this indicator shows an upward tendency. Only in France and West Germany has a declining trend been observed since 1983.

4. The second and third levels comprise all education after primary school. 


\subsubsection{Dual 1_education}

The indicator representing the development of the number of trainees in the dual educational system gives a picture of practice-oriented initial education. The combination of learning and working gives candidates a training that is strongly oriented to practical activities. This is another indicator which relates to the scientific and technological infrastructure for, in particular, the diffusion of technological developments.

The number of trainees in dual education can be derived from the results of the Labour Force Survey (1983-1987) of the European Community. In that survey, persons between the ages of 15 and 49 were asked after the type and purpose of the education 5 they had been following for four weeks previous to the survey. Because for the other countries analysed only absolute student numbers of trainees available, we related all volumes of trainees in dual education to the base year 1985. The index thus composed nicely visualises the development and permits easy comparison with the other countries. Admittedly, international comparability is confined to the member states of the European Comunity; no similar data could be found for the remaining countries.

Table 5. Number of trainees following dual education $(1985=100)$

\begin{tabular}{lrrrrr}
\hline & 1983 & 1984 & 1985 & 1986 & 1987 \\
\hline West Germany & -- & 89 & 100 & 113 & 111 \\
The Netherlands & 109 & -- & 100 & -- & 99 \\
United Kingdom & 135 & 89 & 100 & 91 & 92 \\
Denmark & -- & 86 & 100 & 102 & 106 \\
Greece & 74 & 77 & 100 & 110 & 82 \\
Belgium & 131 & 109 & 100 & 105 & 91 \\
Luxemburg & 83 & 90 & 100 & 88 & 78 \\
Ireland & 112 & 88 & 100 & 81 & 77 \\
Italy & 93 & 107 & 100 & 116 & 117 \\
& & & & & \\
\hline
\end{tabular}

Source : Eurostat/ROA

Legend : -- = not available

The time series of table 5 do fluctuate strongly. The figures may be distorted by shifts in the non-response to the survey, and must therefore be interpreted with some caution.

5. This survey distinguishes 'apprenticeship' (a learning contract) and 'other types of dual education'. 


\subsubsection{Share_of graduates with a technical_education in the total number of graduates of higher education}

The proportion of technically oriented graduates from higher education (Higher Vocational and Scientific Education) indicates the degree of technical skill among the graduates of higher education. High-educated technicians are undoubtedly an important element of the scientific and technological infrastructure, both for the introduction and for the diffusion of technological innovations. This indicator can be computed from data published in the Unesco Statistical Yearbook (1983-1988) and the Unesco Statistical Digest (1983-1987). The following study branches count as technical: mathematics and informatics, engineering, and natural sciences.

From table 6 we can see that the proportion of graduates with a technical education varies much among countries. It is high in the United Kingdom and much lower in the United States. In most countries the proportion of technical graduates is declining; only in West Germany and Japan is it more or less constant. The joining of categories may have distorted the figures for some countries, a fact to be remembered in the comparison (see the footnote to table 6).

Table 6. Percentage share of technical graduates in total number of thirdlevel graduates (ISCED)

\begin{tabular}{|c|c|c|c|c|c|c|}
\hline & $\begin{array}{c}1980 \\
\%\end{array}$ & $\begin{array}{c}1981 \\
\% \\
\end{array}$ & $\begin{array}{c}1982 \\
\%\end{array}$ & $\begin{array}{c}1983 \\
\%\end{array}$ & $\begin{array}{c}1984 \\
\% \\
\end{array}$ & $\begin{array}{c}1985 \\
\% \\
\end{array}$ \\
\hline $\begin{array}{l}\text { France } \\
\text { West Germany } \\
\text { United Kingdom* } \\
\text { Austria** } \\
\text { Sweden } \\
\text { The Netherlands*** } \\
\text { United States } \\
\text { Japan**** }\end{array}$ & $\begin{array}{l}-- \\
-- \\
37 \\
20 \\
-- \\
18 \\
13 \\
--\end{array}$ & $\begin{array}{l}20 \\
15 \\
37 \\
17 \\
-- \\
18 \\
13 \\
19\end{array}$ & $\begin{array}{l}-\overline{14} \\
\overline{17} \\
-- \\
\overline{17} \\
19\end{array}$ & $\begin{array}{l}-\overline{14} \\
27 \\
16 \\
-- \\
15 \\
-- \\
19\end{array}$ & $\begin{array}{l}-- \\
-- \\
28 \\
16 \\
-- \\
-- \\
--\end{array}$ & $\begin{array}{l}-- \\
-- \\
-- \\
13 \\
-- \\
-- \\
14 \\
20\end{array}$ \\
\hline
\end{tabular}

Source : Unesco/ROA

Legend : $--=$ not available

* Including graduates of open university.

** Universities and equivalent institutes.

*** Including craft, commerce and industrial programmes.

**** Including town planning and architecture, craft, commerce, and industrial programmes. 


\subsubsection{Computers in_primary_and secondary_education}

The degree to which students in initial education are made familiar with the use of computers is an obvious indicator of the scientific and technological infrastructure for informatics technology. Both the innovative and the diffusion potential are involved. Unfortunately, in the Netherlands there is no systematic and periodical registration of the use of computers in primary and secondary education. Admittedly, the Ministry of Education and Sciences has carried out a single, large-scale investigation into the use of computers in primary and secondary education in the 1985-6 and 1986-7 school terms. The complete research consisted of partial inquiries addressed to:

- primary education, special education and secondary special education in the 1985-6 term (Inspection report 9);

- lower vocational education, general secondary education, and preuniversity education in the 1985-6 term (Inspection report 12);

- secondary technical education and secondary nautical education in the 1986-7 term (Inspection report 21):

- secondary economic and administrative education, secondary education for small and medium-size enterprise, and secondary hotel and catering education in the 1986-7 term.

These single inquiries took the form of a written questionnaire addressed to all schools. The response was never below 95 per cent, so that the picture gathered from the survey can be considered representative.

To calculate the ratio between the number of computers for educational purposes and the number of students, we should have recourse to the original survey data processed into computer files. The Inspection do provide data about the proportion of schools having one or more computers available for educational purposes 6 .

6. Mark that 'educational purposes' here also include educational management and the like. 
Table 7. Percentage of schools possessing computers for educational purposes

scholastic year $1985 / 1986$

$\%$

Primary schools 27

Primary and secondary special education

Lower vocational education

Multilateral schools for lower vocational education, secondary general education

General secondary education

35

74

86

89

scholastic year 1986/1987

Secondary education

Source: Ministry of Education and Sciences/ROA

The percentage of schools using computers for computer-aided education and/or to teach informatics science and informatics may be a better indicator of the proportion of students made familiar with information technology during their education (see table 8).

Table 8. Percentage of schools employing computers for computer-aided education and for teaching informatics science and informatics (1985-6 school term)

Computer aided education

Primary schools

Primary and secondary special education

Lower vocational education

Lower vocational education and general

secondary education

General secondary education

Computer education/informatics

Primary schools

Primary and secondary special education

Lower vocational education

Lower vocational education and general

secondary education

General secondary education
$\%$

17

25

28

36

34

Source : Ministry of Education and Sciences/ROA

not applicable

not applicable 49

65

71 
The Dutch government has initiated, jointly with private enterprise, several projects to encourage the use of computers in education. The Ministry of Education and Sciences, the companies Philips, IBM and Compudata, and some educational umbrella organisations concluded an agreement on 16 October 1985 to set up a joint-venture project under the title of New Information Technology in Secondary Education. The purpose of this project is to give a co-ordinated impulse to the introduction of new information technologies into secondary education, for the dual purpose of teaching these new technologies and using them to teach existing subjects. The project, which was started in 1986, extends to all schools for lower vocational education, secondary and higher general education, and pre-university education. The intention is to make available by 1989 to all schools of those categories networks consisting of a teacher's computer with eight extensions for students, as well as two computers for subject-specific applications.

After the secondary schools, it will be the turn of primary schools and (secondary) special schools to be provided with computers. In 1990 a start will be made with the supply of equipment, and by 1994 all schools will have personal computers and printers. The provision of computers is realised as a separate project named COMENIUS. Primary schools will be supplied with one basic configuration for, on average, every sixty pupils. Both students and teachers will be able to work with personal computers. The COMENIUS project is supported by the Project of Introduction of New Technology (PRINT), which provides for the development of software and the retraining and accompaniment of teachers in primary and (secondary) special education.

On the international level, too, data about the use of computers are scarce. None of the international organisations are at present registering such figures. On the national level the situation is not much better; the United States of America is the only country to publish data on the use of computers in education in its annual Statistical Abstract of the United States. For France, the only data available refer to 1984.

However, since 1984 an investigation into 'Computers in Education' (the COMPED project) has been going on under the auspices of the International Association for the Evaluation of Educational Achievement. The international co-ordination centre for this investigation has found accommodation with the Research Centre for Applied Education Science (OCTO) of the State University 
of Twente. The purpose is an international comparison of computer use in education. To that end a survey has been conducted in 22 countries. In February 1990 the results of that survey will come available. The survey will be repeated in 1992. The data thus collected may serve to compose an internationally comparable indicator of computer use in education. Whether the survey will be held periodically is by no means certain, however.

\subsection{Labour force and schoolleavers}

\subsubsection{Average level_of education of schoolleavers and the potential labour force}

This section presents indicators representing the average educational level of schoolleavers 7 and of the potential labour force ${ }^{8}$. The average educational level of the potential labour force is indicative of, in particular, the scientific and technological infrastructure for technological progress, the assumption being that workers' responsiveness (flexibility) to technological progress increases with the educational level of the potential labour force.

The average educational level of the technically trained, on the other hand, is indicative of the scientific and technological infrastructure for the generation as well as the diffusion of technological developments. Here both the level of knowledge of the technically educated and their flexibility in the work situation are relevant aspects.

The indicators referring to schoolleavers are of a more dynamic nature; they are a measure of the impulse which the new inflow into the potential labour force gives to both the generation and diffusion of new technology. At the same time they indicate how far initial education succeeds in responding to the extension of the scientific and technological infrastructure and contributes to the solution of adjustment problems on the

7. A schoolleaver is defined here as a student who has left day school in the school year concerned. A correction for migration and mortality has been carried through. Thus, a schoolleaver is a person who joins the potential labour force.

8. The potential labour force refers to the population between 15 and 65 years old. 
labour market ensuing from technological progress (see section 2.3).

To establish the average level of education of the potential labour force in a given year, the average (standardised) number of years of schooling is weighted with the volume of the labour force of each level of schooling in the same year'. With the help of Central Planning Bureau's 'SKILL' model (CPB 1989), we have carried out the exercise both for the entire labour force and for the technically trained labour force.

The average level of education of the labour force has shown a clear upward tendency in the 1980s (see table 9). The expectation is for this trend to continue in the first half of the 1990s. The level of education of the technically educated has also risen, but at a considerably slower pace.

Table 9. Average level of education of the potential labour force

\begin{tabular}{lcc}
\hline & $\begin{array}{c}\text { technically educated } \\
1)\end{array}$ & total labour force \\
\hline $1982 / 83$ & 11.06 & $2)$ \\
$1983 / 84$ & 11.09 & 10.02 \\
$1984 / 85$ & 11.12 & 10.09 \\
$1985 / 86$ & 11.15 & 10.16 \\
$1986 / 87$ & 11.18 & 10.23 \\
$1987 / 88$ & 11.22 & 10.30 \\
$1988 / 89$ & 11.27 & 10.38 \\
$1989 / 90$ & 11.31 & 10.46 \\
$1990 / 91$ & 11.36 & 10.53 \\
$1995 / 96$ & 11.55 & 10.60 \\
$2000 / 01$ & 11.72 & 10.91 \\
& & 11.16 \\
\hline
\end{tabular}

Source : $\mathrm{CPB} / \mathrm{ROA}$

1. Average level of education of the technically educated among the labour force.

2. Average level of education of the entire labour force.

9. For the method of computation, see A. de Grip, Winnaars en verliezers op de arbeidsmarkt. Tijdschrift voor Arbeidsvraagstukken, 1986, pp. 41-51. 
Table 10. Average level of education of schoolleavers*

\begin{tabular}{lcc}
\hline & $\begin{array}{c}\text { technically educated } \\
\text { 1) }\end{array}$ & $\begin{array}{c}\text { total labour force } \\
\text { 2) }\end{array}$ \\
\hline $1982 / 83$ & 11.11 & 11.07 \\
$1983 / 84$ & 11.05 & 11.05 \\
$1984 / 85$ & 11.28 & 11.16 \\
$1985 / 86$ & 11.41 & 11.18 \\
$1986 / 87$ & 11.67 & 11.36 \\
$1987 / 88$ & 12.09 & 11.66 \\
$1988 / 89$ & 12.29 & 11.81 \\
$1989 / 90$ & 12.27 & 11.69 \\
$1990 / 91$ & 12.30 & 11.74 \\
$1995 / 96$ & 12.60 & 11.91 \\
$2000 / 01$ & 12.53 & 11.66 \\
\hline
\end{tabular}

Source: $\mathrm{CPB} / \mathrm{ROA}$

* There are no comparable data for the years 1980 and 1981.

1. Average level of education of schoolleavers from technical schools.

2. Average level of education of schoolleavers from the entire educational system.

Figure I Average level of education of schoolleavers

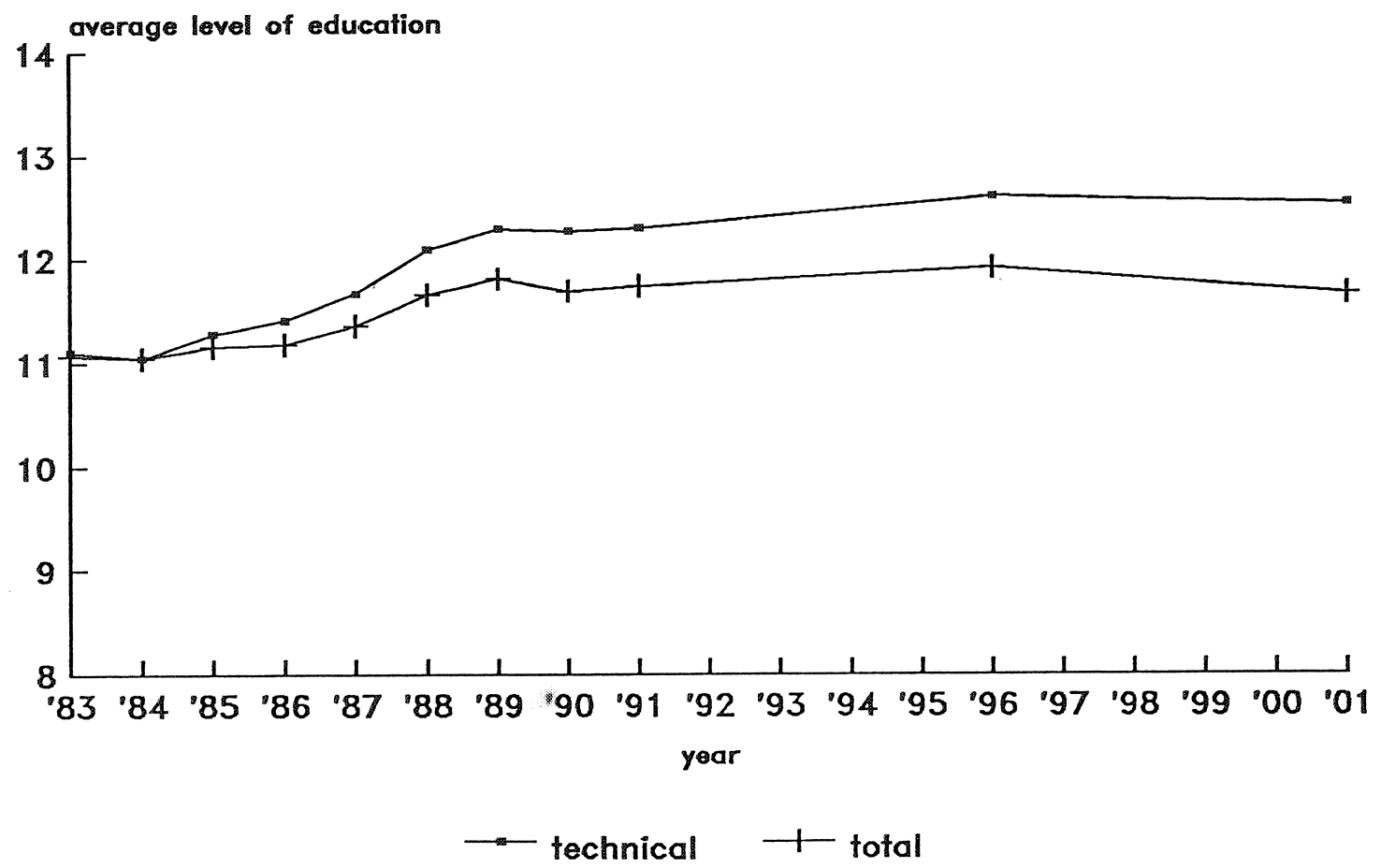

Source: $\mathrm{CPB} / \mathrm{ROA}$ 
Next, table 10 and figure I visualise the level of education of schoolleavers, another indicator derived from the forecast made with the help of the SKILL model. A distinction has again been made between the level of education of all schoolleavers and the average level of education of schoolleavers from technical education in the same year.

The 1980s display a continuous slight rise in the average level of education of the total group of schoolleavers. This time, however, the increase is greater among technically educated schoolleavers than among the total group. That the patterns of the total labour force differs from those of schoolleavers can be explained from the quality of the outflow from the labour force. Apparently, among those leaving the labour force, the technicians have a significantly higher average level of education than the total outflow.

Finally, the indicators of the potential labour force have been related to those of the schoolleavers by calculating the ratio between the average level of education of one year's schoolleavers and the average level of education of the potential labour force (see table 11 and figure II).

Remarkably, the two indicators relating the average educational level of schoolleavers to the average of the potential labour force, are clearly developing in opposite senses. The overall picture shows that the upward impulse to the potential labour force's educational level from the average educational level of schoolleavers has gained strength in the second half of the 1980s. It is expected to decrease in the first half of the $1990 \mathrm{~s}$, however. Another observation is that in the early 1980s the average educational level of schoolleavers gave no boost worth the name to the average level of education of the technically schooled potential labour force. The impulse has increased in the second half of the $1980 \mathrm{~s}$, but is not expected to become much stronger in the 1990 s. 
Table 11. Indicator of the average educational level of schoolleavers in comparison with the potential labour force.

\begin{tabular}{|c|c|c|}
\hline & $\begin{array}{c}\text { indicator technical } \\
\text { education }\end{array}$ & $\begin{array}{c}\text { indicator total } \\
\text { education }\end{array}$ \\
\hline $\begin{array}{l}1982 / 83 \\
1983 / 84 \\
1984 / 85 \\
1985 / 86 \\
1986 / 87 \\
1987 / 88 \\
1988 / 89 \\
1989 / 90 \\
1990 / 91 \\
1995 / 96 \\
2000 / 01\end{array}$ & $\begin{array}{l}100 \\
100 \\
101 \\
102 \\
104 \\
108 \\
109 \\
108 \\
108 \\
109 \\
107\end{array}$ & $\begin{array}{l}111 \\
110 \\
110 \\
109 \\
110 \\
112 \\
113 \\
111 \\
111 \\
109 \\
104\end{array}$ \\
\hline
\end{tabular}

Source : $\mathrm{CPB} / \mathrm{ROA}$

1) Percentage relation between the level of education of the technically educated among schoolleavers and the average level of education of the technically educated in the potential labour force.

2) Percentage relation between the level of education of schoolleavers and the average level of education of the potential labour force.

Figure II Indicator of the average level of education of schoolleavers in comparison with the potential labour force

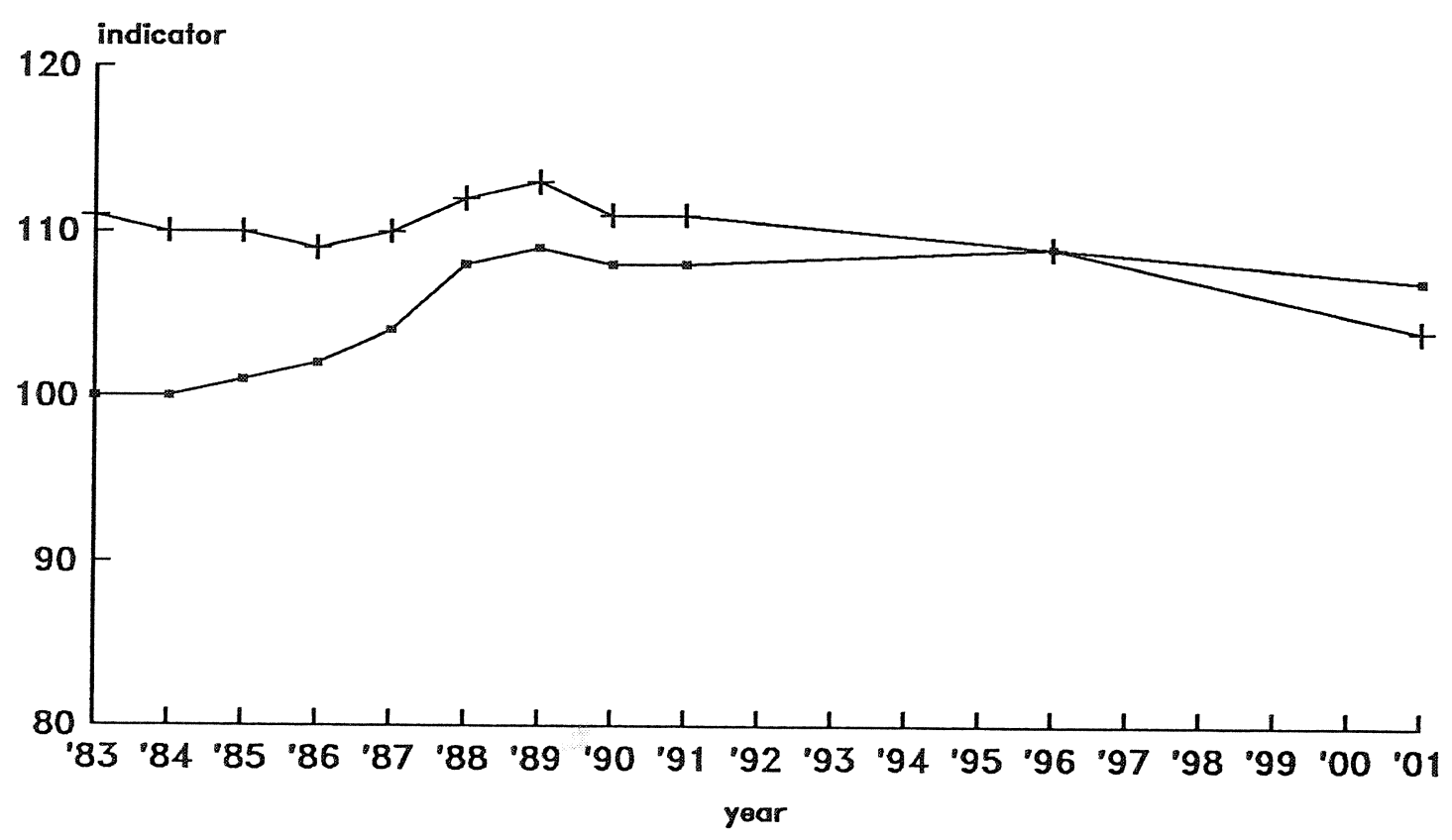

- technical -1 total

Source: $C P B / R O A$ 
Publications of international organisations do not provide data from which to derive the average level of education of the labour force in other countries. UNESCO does publish data on the level of education of the labour force, but they are available only for census years ten years apart, and thus are no use for drawing up time series. However, for Sweden the average level of education of the labour force could be computed, for several years, from the Swedish Labour Force Surveys. The results are reproduced in table 12. Similar data are available for Austria. From table 12, the average level of education is rising in Sweden, and is somewhat higher than in the Netherlands. Remember, however, that institutional differences between the countries' educational systems make the average levels of education hard to compare. On that account, the available data are suited most to visualising the development patterns within one country.

Table 12. Average level of education in Sweden

\begin{tabular}{lrr}
\hline & years & index \\
\hline 1975 & 9.60 & 93 \\
1980 & 10.28 & 100 \\
1981 & 10.41 & 101 \\
1982 & 10.52 & 102 \\
1983 & 10.68 & 104 \\
1984 & 10.81 & 105 \\
1985 & 11.00 & 107 \\
\hline
\end{tabular}

Source : Sveriges Officiella Statistik Statistiska Centralbyrån/ROA

For France, Japan, and West Germany, data about the average level of education of schoolleavers are available in a crude form. Frequently the data for the lowest levels are lacking, however. In principle, the level of education of schoolleavers can be computed for the three countries just mentioned. However, in view of the additional work involved, we have decided not to do so.

\subsubsection{Share of technically educated in the total number of school leavers and in the potential labour force}

In this section, the shares of technically educated in the labour force and in the total number of schoolleavers will be computed. The share of the technically educated in the potential labour force is an indicator of the 
scientific and technological infrastructure of society, both for the creation and the diffusion of technology. The ratio between the shares of schoolleavers and the potential labour force (column 3 of the tables and figure III) is a more dynamic indicator of the development of this infrastructure.

With the help of SKILL 1989 of the Central Planning Bureau, the share of technically educated in the potential labour force (see figure IV) and the share of technically educated in a year's schoolleavers (see figure V) can be calculated. We have observed values from the recent past as well as developed forecasts for the future.

Table 13. Share of technically educated (schoolleavers and potential labour force)

\begin{tabular}{cccc}
\hline & $\begin{array}{c}\text { schoolleavers } \\
1)\end{array}$ & $\begin{array}{c}\text { labour force } \\
\text { 2) } \\
\%\end{array}$ & $\begin{array}{c}\text { indicator } \\
\text { \%) }\end{array}$ \\
\hline $1982 / 83$ & 22.0 & 23.4 & \\
$1983 / 84$ & 22.4 & 23.6 & 94 \\
$1984 / 85$ & 22.1 & 23.9 & 95 \\
$1985 / 86$ & 21.5 & 24.2 & 89 \\
$1986 / 87$ & 21.0 & 24.5 & 86 \\
$1987 / 88$ & 20.3 & 24.7 & 82 \\
$1988 / 89$ & 19.6 & 24.9 & 79 \\
$1989 / 90$ & 19.7 & 25.1 & 79 \\
$1990 / 91$ & 19.1 & 25.2 & 76 \\
$1995 / 96$ & 19.3 & 25.7 & 75 \\
$2000 / 01$ & 19.1 & 25.8 & 74 \\
\hline
\end{tabular}

Source : $\mathrm{CPB} / \mathrm{ROA}$

1) Share of technically educated schoolleavers.

2) Share of technically educated in the labour force.

3) Ratio between the share of technically educated schoolleavers and the corresponding share in the potential labour force.

What strikes us in table 13 and figure III is that the indicator of technically educated has a value of less than 100. This means that the inflow of schoolleavers, ceteris paribus, diminishes the share of technically educated in the potential labour force. Besides, from the (sub)indicator of the first column the share of technically educated in the yearly number of schoolleavers appears to be declining further in the 1990s, a development which gives rise to concern. 
Figure III Indicator of the share of (higher) technically educated

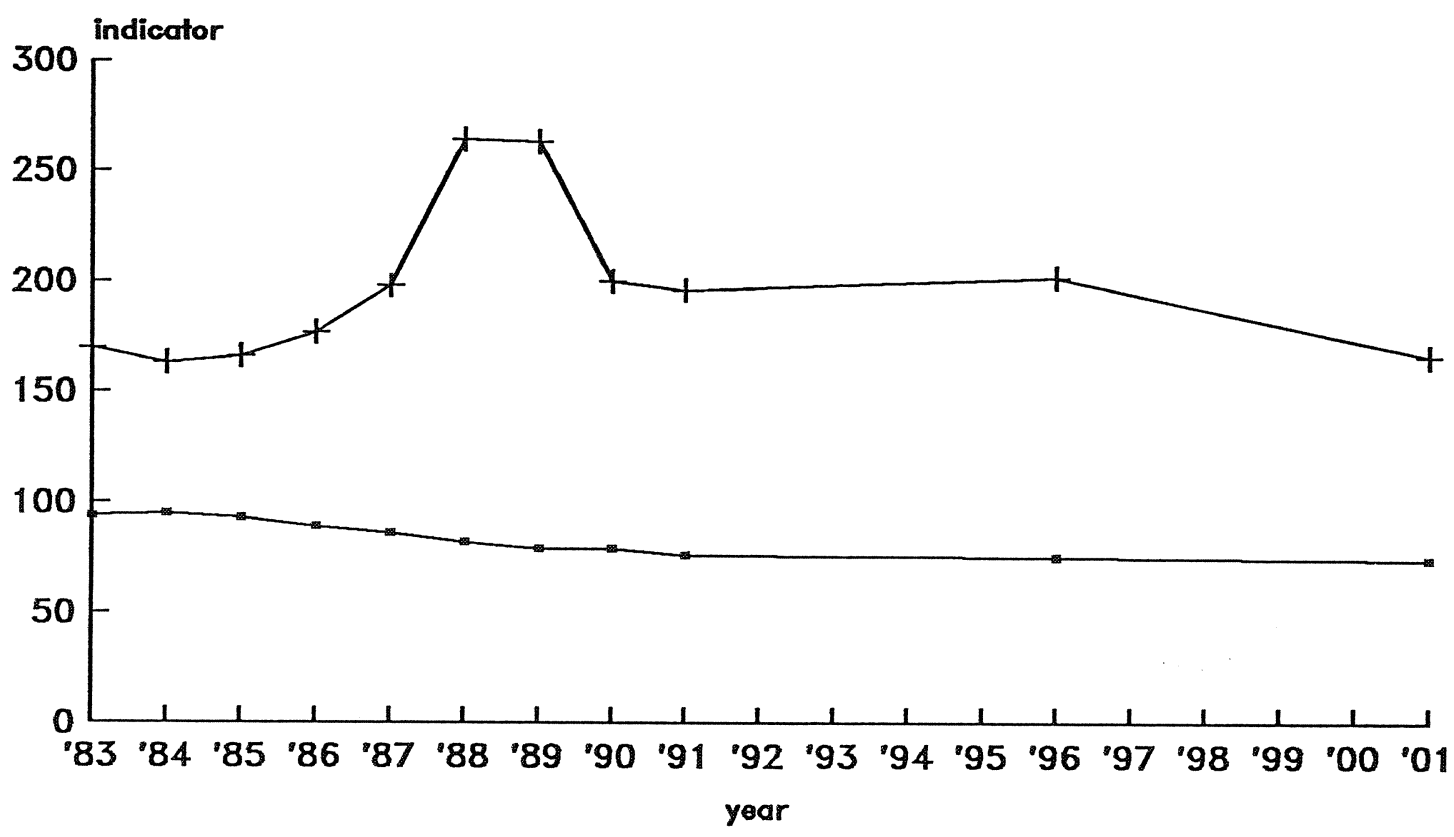

$\rightarrow$ total T higher

\section{Source : $\mathrm{CPB} / \mathrm{ROA}$}

Figure IV Share of technically educated

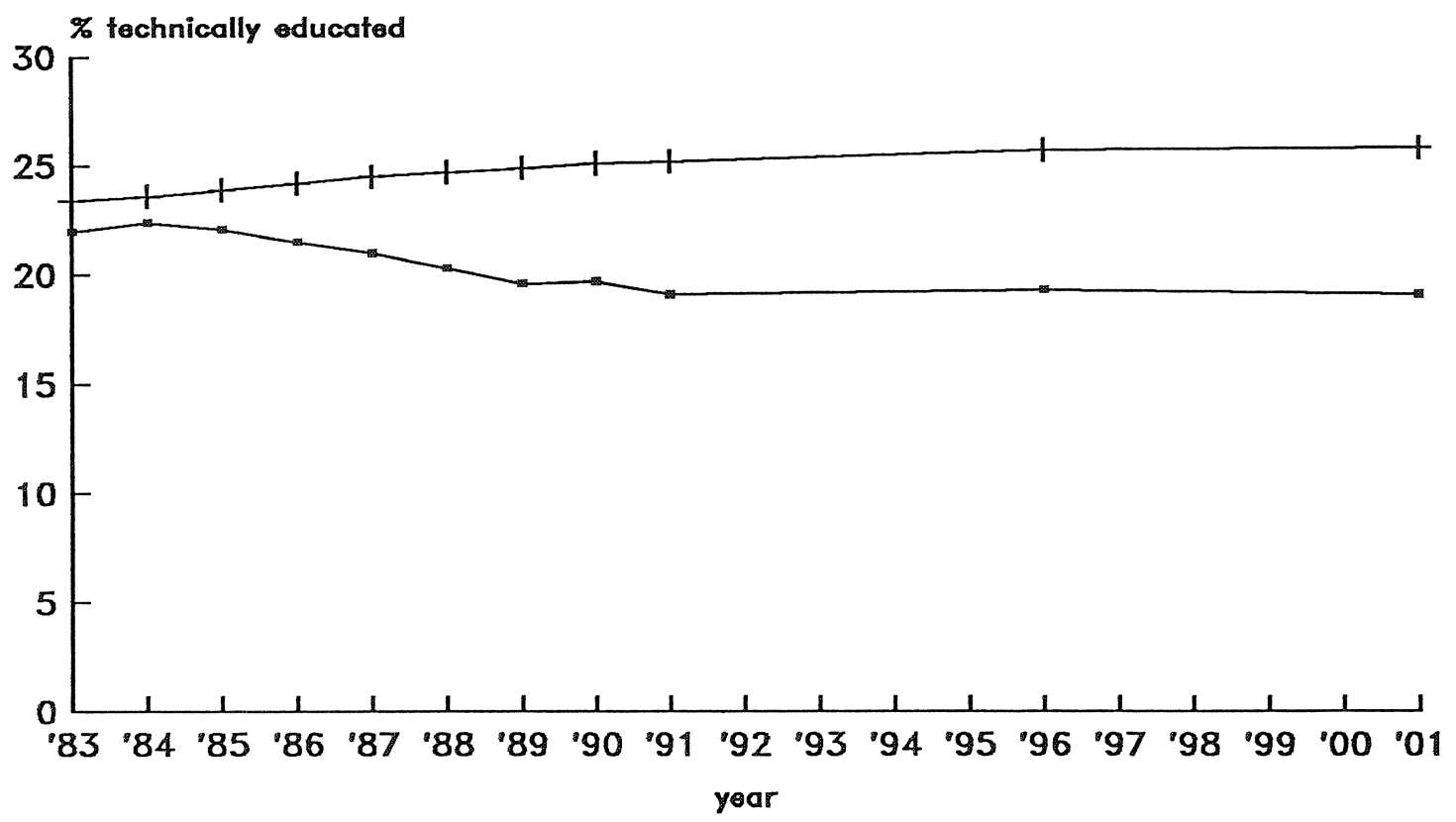

- schoolleavers 1 potent. labour force 
The same indicator can be calculated for the higher educated technicians (Higher Vocational Education and Scientific Education). From table 14 and figure $V$, the indicator for the higher educated far exceeds 100, which suggests a clear positive impulse from the entrants on the labour market on the average share of higher-schooled technicians in the potential labour force. At the same time, the steep decline of the share of technically educated (see table 13) appears to result from a fast diminishing share of schoolleavers with secondary and lower levels of technical education in the outflow from the educational system.

Table 14. Share of higher-educated technicians (schoolleavers and potential labour force)

\begin{tabular}{lccc}
\hline & $\begin{array}{c}\text { schoolleavers } \\
1 \text { ) } \\
\%\end{array}$ & $\begin{array}{c}\text { potential } \\
\text { labour force } \\
2 \text { ) } \\
\%\end{array}$ & $\begin{array}{c}\text { indicator } \\
\text { (a) }\end{array}$ \\
\hline $1982 / 83$ & 1.51 & 0.89 & 170 \\
$1983 / 84$ & 1.50 & 0.92 & 163 \\
$1984 / 85$ & 1.59 & 0.96 & 166 \\
$1985 / 86$ & 1.75 & 0.99 & 177 \\
$1986 / 87$ & 2.04 & 1.03 & 198 \\
$1987 / 88$ & 2.89 & 1.09 & 264 \\
$1988 / 89$ & 3.09 & 1.18 & 263 \\
$1989 / 90$ & 2.53 & 1.26 & 200 \\
$1990 / 91$ & 2.60 & 1.32 & 196 \\
$1995 / 96$ & 3.32 & 1.65 & 202 \\
$2000 / 01$ & 3.24 & 1.95 & 166 \\
& & & \\
\hline
\end{tabular}

Source: $\mathrm{CPB} / \mathrm{ROA}$

1) Share of higher educated technicians in a year's schoolleavers.

2) Share of higher educated technicians in the potential labour force.

3) Percentage ratio between the shares of higher educated technicians in one year's schoolleavers and in the potential labour force.

No comparable figures for other countries can be found in publications of international organisations or national statistical offices. Possibly, however, such figures can be found among the internal data of national statistical offices and/or planning agencies. 
Figure $V$ Share of higher educated technicians

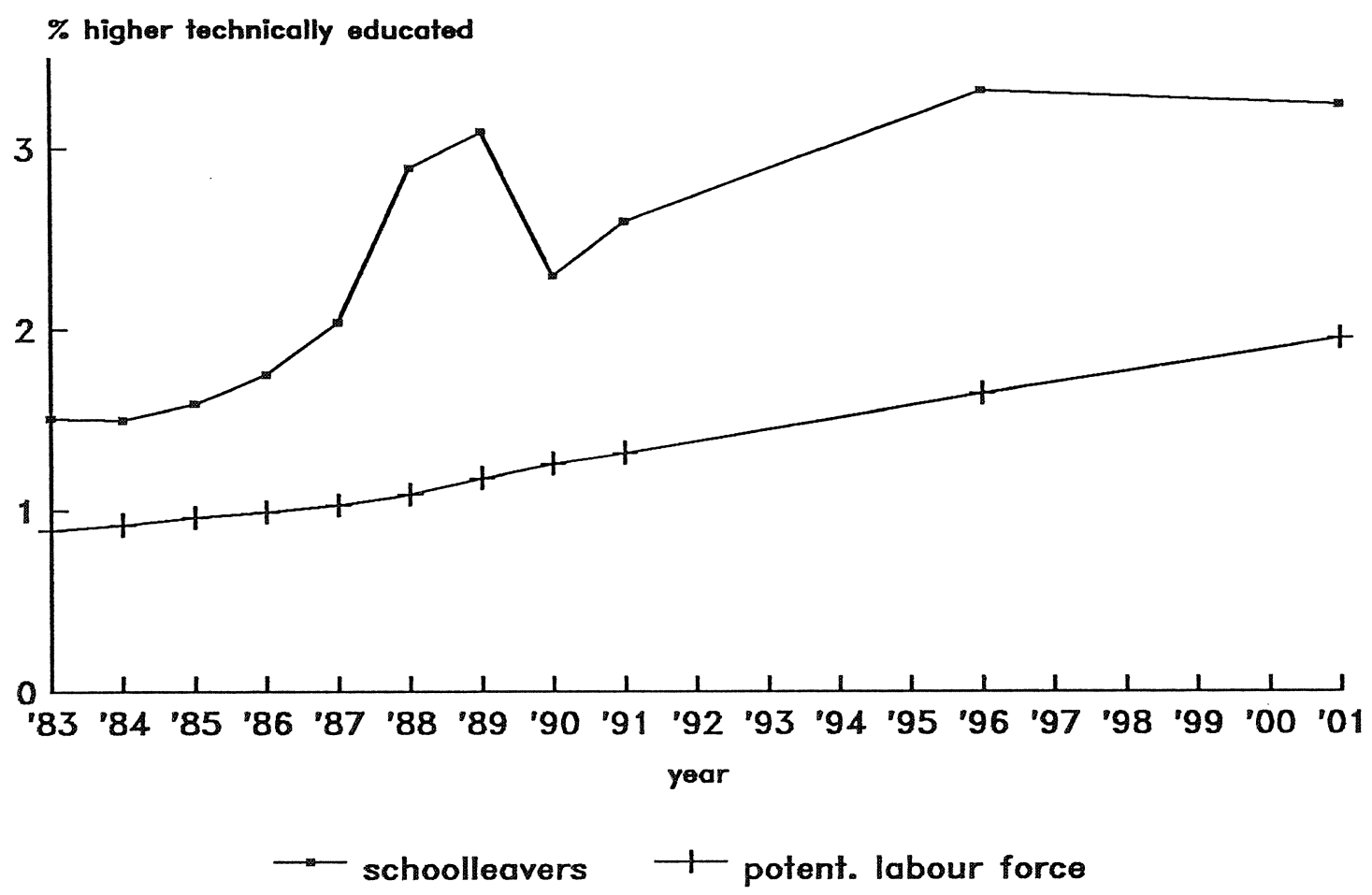

Source: $\mathrm{CPB} / \mathrm{ROA}$

\subsubsection{Share_of technically educated in management occcupations}

The indicator to be presented here concerns the share of the technically educated in management occupations. The MEASUREMENT paper describes it as indicative of the societal infrastructure for technological developments. A more accurate expresion would be 'indicative of the scientific and technological infrastructure. The indicator represents the technological perceptiveness of corporate management. It could be regarded as indicative of the scientific or technological infrastructure for both the introduction of technological innovations (the innovative potential) and the diffusion of technological developments (the diffusion potential).

For the Netherlands, the share of technically educated in management occupations can be computed from data deriving from the Labour Force Censuses. These were conducted once every two years by the CBS up to 1987 , when they were replaced with the Labour Force Survey. The labour-force censuses classifies schools by codes of the Standard Education Classification (more or les equivalent with ISCED), and distinguished the following types of technical education: 
code: description:

31 education in mathematics and natural sciences

36 technical education without further differentiation

38 technical education with economic, clerical or commercial differentiation.

The labour-force census classifies occupations by CBS occupation code (more or less equivalent with ISCO). The most detailed level on which a relation between education and occupation can be established is that of the two-digit occupational class. The CBS distinguishes the following management occupations:

code: $\quad$ description:

20 managing and higher executive functions in public government;

21 managing and higher executive functions exclusive of public government;

40 directors and managers in wholesale trade;

41 directors and managers in retail trade;

50 directors and managers in hotels and catering;

51 self-employed owners of hotels, restaurants and cafés.

From the 1979, 1981, 1983 and 1985 labour-force censuses we can derive what we would call a broad indicator of the proportion of technically educated persons in management occupations. Since obviously there are hardly any technicians occupied in the relatively small occupational classes 50 and 51 , perhaps a more narrowly defined indicator (based on the occupational classes 20, 21, 40 and 41) would be preferable. Both indicators are represented in table 15 and figure VI.

Table 15. Share of technically educated in management occupations

\begin{tabular}{lcc}
\hline & broad indicator & narrow indicator \\
$\%$ & $\%$ \\
\hline 1979 & 25.2 & 29.8 \\
1981 & 24.6 & 28.8 \\
1983 & 28.3 & 32.0 \\
1985 & 27.6 & 30.9 \\
\hline
\end{tabular}

Source : CBS/ROA 
Figure VI Share of technically educated in management occupations

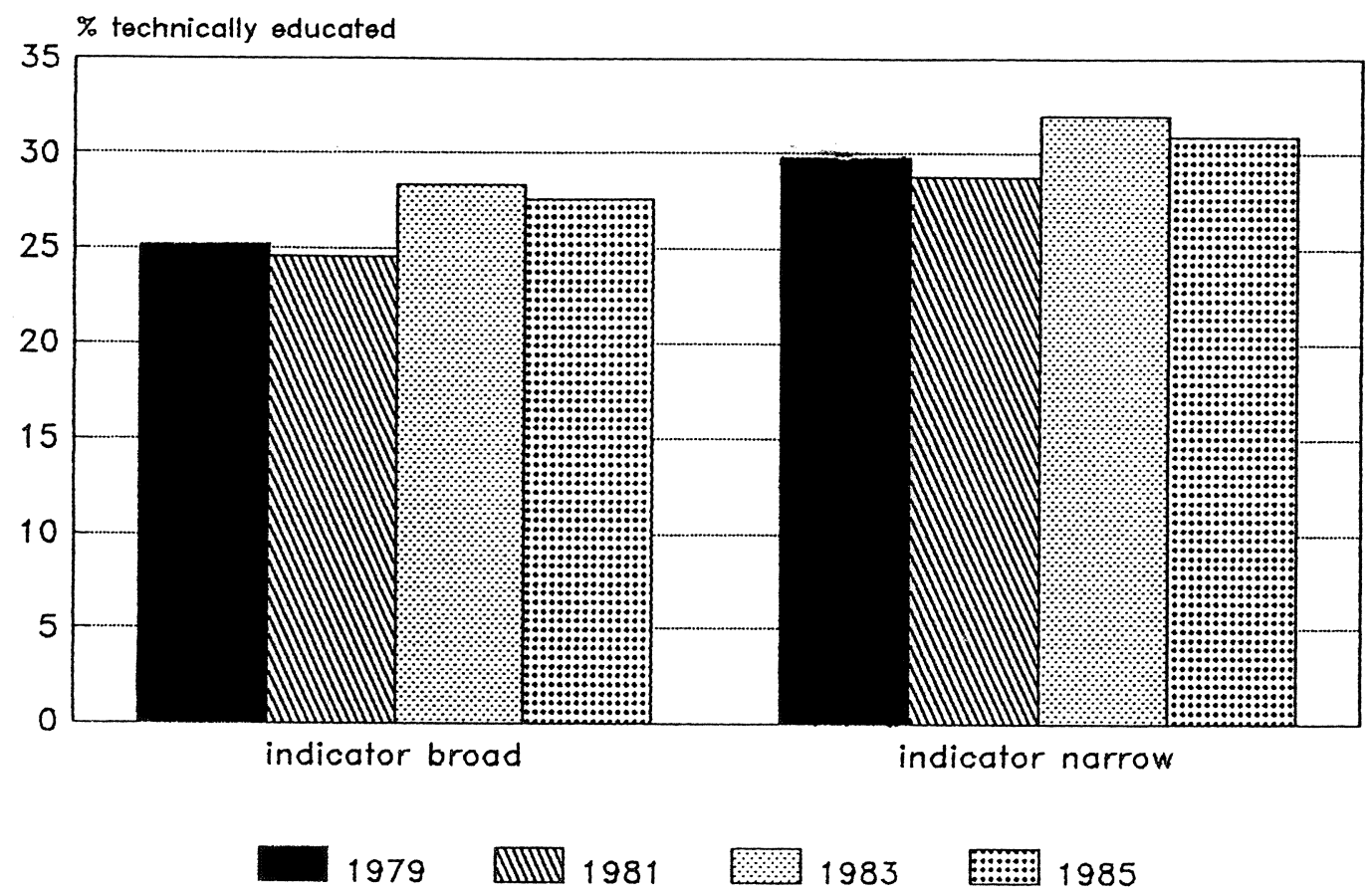

Source : CBS/ROA

Table 15 shows a slight increase in the share of technically educated in management occupations in the broad sense between 1981 and 1983, which did not persist beyond that period. The series representing the number of technically educated in managerial occupations in the narrow sense shows a similar pattern on a higher level.

Next, the share of higher educated technicians (Higher Vocational Education and University education) in management occupations was established, again in the broad and narrow senses.

Table 16. Share of higher educated technicians in management occupations

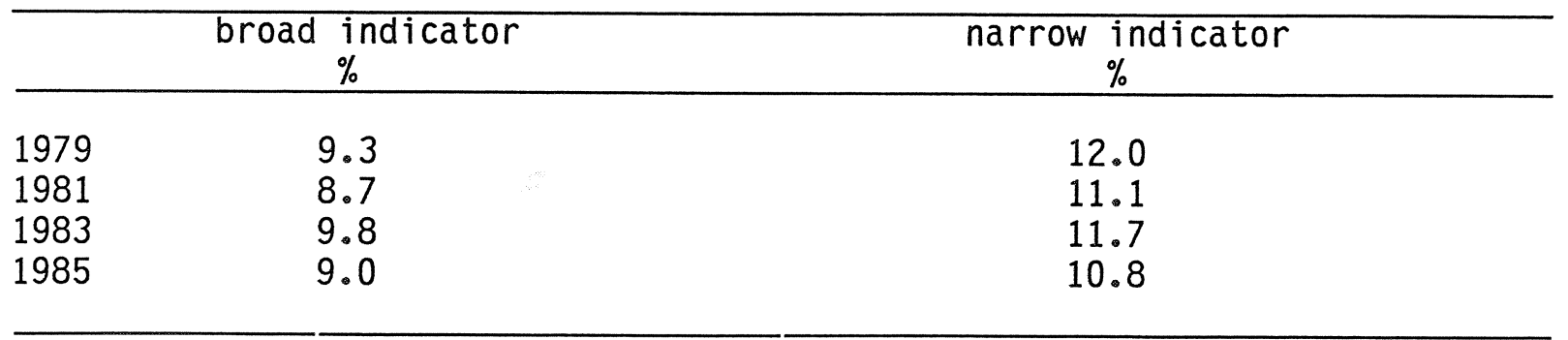

Source: $\mathrm{CBS} / \mathrm{ROA}$ 
Figure VII Share of higher educated technicians in management occupations

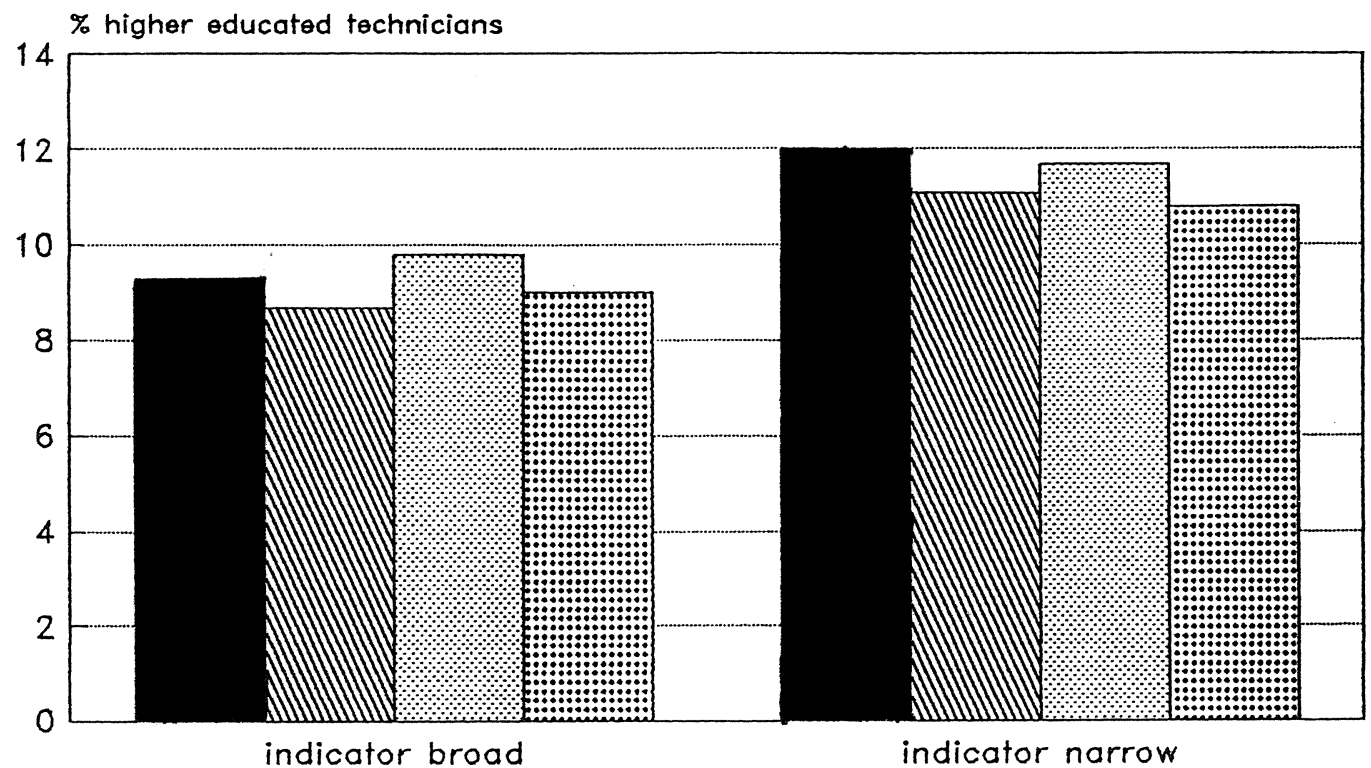

1979 औIII 1981 \% 1983

Source : CBS/ROA

The proportion of higher educated technicians in management occupations in the broad sense fell slightly in the 1979-1985 period. The same pattern prevails for the narrow indicator, again, as could be expected, on a higher plane.

Although there are no significant references between the development of time series of (higher) technically educated in management occupations in the narrow and the broad sense, we would plead the use of the 'narrow' indicator, in view of the insignificant proportion of technically educated persons in occupational classes 50 and 51.

In principle, the above indicators can also be derived from the LabourForce Surveys conducted since 1987. However, on account of teething troubles the CBS has not yet been able to publish educational data from that source. Nor are comparable data for other countries available. International organisations as Unesco, ILO, OECD or the European Community do not include them in their yearbooks, nor do they seem to have them available for internal use. Yearbooks and other publications of the various national statistical bureaus do not include these data. However, as these figures are also not published by the Dutch Bureau of Statistics, similar data might also be available internally with the other national statistical bureaus. 


\subsection{Need for training}

\subsubsection{Tensions in the labour-market situation of technically skilled_people}

Van Paridon has developed a labour-market indicator expressing the share of schoolleavers of the latest year class that is still unemployed (see De Grip and Heijke 1988). This indicator of labour market tensions makes use of the unemployment figures registered with the District Labour Exchanges, corrected for distortions 10 . It can be employed in principle to identify tensions that could impede the diffusion of technological progress.

Table 17 describes the unemployment situation in the years 1986 to 1988. From the table, the labour-market situation of technicians appears to be (relatively) tight, while on the whole the labour market is still relatively easy.

No internationally comparable data are to be found in publications of international organisations or national statistical offices. Perhaps they can be taken from internal information with national statistical offices.

\subsubsection{Share of over-thirties_persons in the economically active_population}

Another indicator to be considered is the proportion of persons at the age thirty and over in the economically active population11. This indicator can be considered a measure of the need for retraining, on the assumption that technical progress tends to make the initial education of the labour force obsolete. For the over-thirties to remain economically employable, they need retraining. In other words: the share of over-thirties in the total labour force is indicative of the vulnerability of the labour force to Table 17.

10. Following Van Paridon we assume that the files of schoolleavers are highly distorted (60 per cent), because many young workers do not have their names removed when working for employment agencies or performing other kinds of temporary work.

11. ILO defines the economically active population as all individuals who contribute to the supply of labour for the production of goods and services. Both working people and unemployed people belong to the active population (ILO, 1989). Students, old-age pensioners and women not participating in the labour process, on the contrary, are excluded. Moreover, the definitions of active population vary among countries. 
Percentage of unemployment among schoolleavers (May figures)

\begin{tabular}{|c|c|c|c|}
\hline & $\begin{array}{c}1986 \\
\%\end{array}$ & $\begin{array}{c}1987 \\
\%\end{array}$ & $\begin{array}{c}1988 \\
\%\end{array}$ \\
\hline $\begin{array}{l}\text { - Lower Vocational Education } \\
\text { - Lower Technical Schools }\end{array}$ & $\begin{array}{l}19 \\
13\end{array}$ & $\begin{array}{l}15 \\
10\end{array}$ & $\begin{array}{l}15 \\
10\end{array}$ \\
\hline $\begin{array}{l}\text { - Intermediate Vocational Education } \\
\text { - Intermediate Technical Schools } \\
\text { mechanical engineering } \\
\text { energy technics } \\
\text { electronics } \\
\text { process engineering }\end{array}$ & $\begin{array}{l}9 \\
5 \\
4 \\
2 \\
6 \\
4\end{array}$ & $\begin{array}{l}8 \\
4 \\
3 \\
2 \\
5 \\
5\end{array}$ & $\begin{array}{r}10 \\
4 \\
4 \\
3 \\
6 \\
8\end{array}$ \\
\hline $\begin{array}{l}\text { - Higher Vocational Education } \\
\text { - Higher Technical Schools } \\
\text { electrotechnics } \\
\text { informatics } \\
\text { mechanical engineering } \\
\text { management }\end{array}$ & $\begin{array}{r}12 \\
4 \\
3 \\
2 \\
2 \\
2\end{array}$ & $\begin{array}{r}10 \\
4 \\
2 \\
3 \\
2 \\
4\end{array}$ & $\begin{array}{r}12 \\
5 \\
6 \\
3 \\
4 \\
4\end{array}$ \\
\hline $\begin{array}{l}\text { - Academic Sciences } \\
\text { - Technical Sciences } \\
\text { electrotechnics } \\
\text { mathematics } \\
\text { informatics } \\
\text { management }\end{array}$ & $\begin{array}{r}11 \\
6 \\
3 \\
3 \\
-- \\
7\end{array}$ & $\begin{array}{r}10 \\
5 \\
1 \\
4 \\
3 \\
5\end{array}$ & $\begin{array}{l}9 \\
5 \\
4 \\
6 \\
2 \\
3\end{array}$ \\
\hline Total & 14 & 11 & 12 \\
\hline
\end{tabular}

Source: Van Paridon/ROA

Legend : -- = not available

technological progress. It is also indicative of the required intragenerational mobility 12 inasmuch as technological developments entail shifts in the occupational structure. Besides, the indicator marks how much leeway countries have to adjust initial education to occupational practice, thus responding to changed educational demands due to technological progress. The higher the value of the indicator, the narrower the leeway for adjusting initial education to the labour market, and the greater the need to retraining adults in compensation. The proportion of over-thirties in the labour force is thus an important indicator of the scientific and technological infrastructure for the diffusion of technological progress. Naturally, thirty is a somewhat arbitrary age limit: it is merely an indication of the shrinking proportion of youngsters in the population, and

12. See A. de Grip, Onderwijs en Arbeidsmarkt: Scholingsdiscrepanties, Amsterdam, 1987. 
the ensuing relative drop in the inflow of recently skilled workers into the labour market.

From the Yearbook of Labour Statistics of the ILO (1982-1988), the share of the age group of thirty and over in the labour force has been computed for the 1986-7 period.

Table 18. Percentage share of 30 and over in the active population

\begin{tabular}{lcccccccc}
\hline & $\begin{array}{c}1980 \\
\%\end{array}$ & $\begin{array}{c}1981 \\
\%\end{array}$ & $\begin{array}{c}1982 \\
\%\end{array}$ & $\begin{array}{c}1983 \\
\%\end{array}$ & $\begin{array}{c}1984 \\
\%\end{array}$ & $\begin{array}{c}1985 \\
\%\end{array}$ & $\begin{array}{c}1986 \\
\%\end{array}$ & $\begin{array}{c}1987 \\
\%\end{array}$ \\
\hline United States & 62 & 62 & 62 & -- & 64 & 65 & 65 & 66 \\
Japan & 76 & 77 & 77 & 77 & 78 & 78 & 78 & 78 \\
Austria & 67 & 63 & 64 & 64 & 62 & 62 & 62 & 62 \\
France & 68 & 68 & 69 & 69 & 69 & 70 & 70 & 72 \\
West Germany & 68 & 68 & 68 & 68 & 68 & 67 & 67 & -- \\
The Netherlands & 63 & 63 & 63 & 63 & -- & -- & 64 & 63 \\
Sweden & 74 & -- & 73 & 73 & 73 & 73 & 73 & 73 \\
United Kingdom & -- & 68 & -- & -- & -- & -- & -- & -- \\
& & & & & & & & \\
\hline
\end{tabular}

Source: ILO/ROA.

Legend : -- = not available.

From table 18 can be derived that the Netherlands and the United States have a relatively young labour force, while in Japan and Sweden the proportion of over-thirties is much higher. While the proportion of older labour supply is observed in the 1980s to have increased in some of the countries included in the analysis, it is contracting in Austria, and has remained more or less constant in West Germany, Sweden and Netherlands.

The possibility could be considered to use forecasts of the future share of senior citizens in the (potential) labour force to compute this indicator. Such forecasts are available for the Netherlands, and the assumption is warranted that in various other countries, too, forecasts are made of the future age composition of the population. Communication with national planning offices could clarify that point.

\subsection{Training efforts}

\subsubsection{Training_expenditure}

The indicators presented in this section represent the educational efforts of the various sectors of activity in our country, measured by the amounts 
of money spent on training courses 13 . By training courses are understood here courses organised by companies and institutions for their own staff 14 . The indicators developed on that basis can be considered indicative of the scientific and technological infrastructure for, in particular, the diffusion of technological developments. Such in-company training courses are a supplement to initial education and can be regarded as a means to keep abreast of fast (technological) progress. The amounts spent on training are thus a measure of the flexibility of people in employment towards technical progress. They also indicate how much is invested in the enhancement or maintenance of the human capital incorporated in employed persons.

By means of a survey, the CBS has collected information about the training efforts of companies and institutions. The CBS is considering the possibility of holding an inquiry into in-company training courses every other year, but has not yet decided to do so. From the CBS publication 'Bedrijfsopleidingen in Nederland' (1986), which presents the results of the 1986 survey, data with respect to the training efforts of the individual sectors of activity in the Netherlands can be borrowed (see table 19).

Table 19. Indicators of training expenditure by sector of activity

\begin{tabular}{lrrr}
\hline Sector of activity & 1) & 2) & 3) \\
\hline Agriculture and fishing & 4 & 4 & 0.2 \\
Manufacturing and mining & 31 & 779 & 1.6 \\
Electricity, gas and water & 31 & 48 & 1.8 \\
Construction & 8 & 45 & 0.3 \\
Trade and catering & 12 & 201 & 0.8 \\
Transport, storage and communication & 32 & 482 & 2.7 \\
Banking, insurance and commercial services & 45 & 573 & 2.3 \\
Other services & 17 & 160 & -- \\
& & & 1.5 \\
Total & 25 & 2292 & \\
\hline
\end{tabular}

Source : CBS

Legend : $--=$ not available

1. Number of participants in training courses as a percentage of the total number of employed in the sector.

2. Total training expenditure (in millions of guilders). This sum includes the expenses for training departments and training officers, outlays on training institutes, reimbursement of study expenses, and the cost of foregone worktime.

3. Training expenditure as a percentage of wage costs.

13. The percentage of employed persons following a course of training organised by companies or branches.

14. CBS 1988. 
The same CBS publication permits breaking down the above table to company size. Three categories have been distinguished, namely small enterprise (5100 employed), medium-size enterprise (100-500 employed), and large companies $(\geq 500)$.

Table 20. Number of participants in training courses as a percentage of the number of employed

\begin{tabular}{lccc}
\hline Sector of activity & \multicolumn{3}{c}{$\begin{array}{c}\text { Firm size } \\
\text { (number of workers) }\end{array}$} \\
& $5-<100$ & $100-<500$ & $>500$ \\
\hline Agriculture and fishing & 3 & 11 & -- \\
Manufacturing and mining & 8 & 21 & 59 \\
Electricity, gas and water & 13 & 17 & 43 \\
Construction & 4 & 15 & 24 \\
Trade and catering & 8 & 20 & 17 \\
Transport, storage and communication & 5 & 18 & 46 \\
Banking, insurance and commercial services & 26 & 49 & 64 \\
Other services & 11 & 22 & 20 \\
Total & 10 & 25 & 46 \\
\end{tabular}

Source : CBS

Legend : -- = not available

Table 21. Total training expenses (in min guilders)

\begin{tabular}{|c|c|c|c|}
\hline \multirow[t]{2}{*}{ Setor of activity } & \multicolumn{3}{|c|}{$\begin{array}{l}\text { Firm size } \\
\text { (number of workers) }\end{array}$} \\
\hline & $5-<100$ & $100-<500$ & $>500$ \\
\hline $\begin{array}{l}\text { Agriculture and fishing } \\
\text { Manufacturing and mining } \\
\text { Electricity, gas and water } \\
\text { Construction } \\
\text { Trade and catering } \\
\text { Transport, storage and comminication } \\
\text { Banking, insurance and commercial services } \\
\text { Other services }\end{array}$ & $\begin{array}{r}3 \\
59 \\
3 \\
15 \\
52 \\
12 \\
106 \\
47\end{array}$ & $\begin{array}{r}1 \\
116 \\
9 \\
16 \\
52 \\
14 \\
136 \\
52\end{array}$ & $\begin{array}{r}-- \\
604 \\
36 \\
14 \\
97 \\
456 \\
331 \\
61\end{array}$ \\
\hline Total & 297 & 396 & 1599 \\
\hline
\end{tabular}

Source : CBS

Legend : $--=$ not available 
Table 22. Training expenses as a percentage of wage costs

\begin{tabular}{lccc}
\hline Sector of activity & \multicolumn{3}{l}{$\begin{array}{l}\text { Firm size } \\
\text { (number of workers) }\end{array}$} \\
& $5-<100$ & $100-<500$ & $>500$ \\
\hline Agriculture and fishing & 0.2 & 0.6 & -- \\
Manufacturing and mining & 0.4 & 1.0 & 2.7 \\
Electricity, gas and water & 1.3 & 1.1 & 2.2 \\
Construction & 0.2 & 0.5 & 0.9 \\
Trade and catering & 0.3 & 1.0 & 2.0 \\
Transport, storage and communication & 0.2 & 0.7 & 4.3 \\
Banking, insurance and commercial services & 1.1 & 2.8 & 3.1 \\
Other services & -- & -- & -- \\
Total & 0.5 & 1.2 & 2.9 \\
\hline
\end{tabular}

Source : CBS

Legend : -- = not available

Tables 20 to 22 show that the training efforts of small and medium-size enterprise remain far below those of large companies (500 or more employed). Especially companies employing fewer than 100 workers spend little effort on training. The pattern is the same in all sectors.

So far, we have not been able to establish similar data for other countries. A comparison will anyhow be difficult, because probably the definition of training expenditure differs from one country to another, in particular as regards the inclusion of lost worktime in the expenses.

\subsubsection{Proportion of the potential labour force_participating in training}

In this section the proportion of the potential labour force between the ages of 15 and 49 following (non-initial) training courses is presented as an indicator. Training is an important means to respond to technological progress. The Labour Force Survey organised yearly by the European Community produces data on the type of training followed for four weeks prior to the survey. These data are available for the years 1983 through 1987. Persons between the ages of 15 and 49 are interviewed about the type and objective of the training followed. From the data thus gathered can be established what proportion of the potential labour force between the ages of 15 and 49 is engaged in training. Two variants of this indicator can be calculated, 
referring to training in a narrow and in a wide sense. Training in the wide sense is understood to comprise 'on-the-job training, apprenticeship, dual system' and 'other training', in other words, all types of training that are combined with a job (see table 23).

In the narrow sense (see table 24) training refers only to 'on-the-job training'. More basic types of vocational training, such as apprenticeships, are excluded from this indicator.

To compute the indicators, the number of people taking part in a training course during the four weeks prior to the survey has been related to the total population between the ages of 15 and 49. These indicators can be considered indicative of the scientific and technological infrastructure for, in particular, the diffusion of technological advance.

Table 23. Participation in training (in the wide sense) by the potential labour force between the ages of 15 and 49

\begin{tabular}{|c|c|c|c|}
\hline \multirow[t]{2}{*}{ Sector of activity } & \multicolumn{3}{|c|}{$\begin{array}{l}\text { Firm size } \\
\text { (number of workers) }\end{array}$} \\
\hline & $5-<100$ & $100-<500$ & $>500$ \\
\hline $\begin{array}{l}\text { Agriculture and fishing } \\
\text { Manufacturing and mining } \\
\text { Electricity, gas and water } \\
\text { Construction } \\
\text { Trade and catering } \\
\text { Transport, storage and communication } \\
\text { Banking, insurance and commercial services } \\
\text { Other services }\end{array}$ & $\begin{array}{l}0.2 \\
0.4 \\
1.3 \\
0.2 \\
0.3 \\
0.2 \\
1.1 \\
-.\end{array}$ & $\begin{array}{l}0.6 \\
1.0 \\
1.1 \\
0.5 \\
1.0 \\
0.7 \\
2.8 \\
--\end{array}$ & $\begin{array}{l}2 .- \\
2.7 \\
0.2 \\
2.0 \\
4.3 \\
3.1 \\
-.\end{array}$ \\
\hline Total & 0.5 & 1.2 & 2.9 \\
\hline
\end{tabular}

Source : CBS

Legend : $--=$ not available

Table 23 shows that the participation in training in the wide sense is highest in Denmark, and extremely low in Greece and Italy. In most countries training participation remained more or less on a level throughout the 1983-87 period; only in West Germany and Denmark is a rising tendency observable. Table 24 reproduces the training participation in the narrow sense, including only on-the-job training. The pattern is largely similar to that of the indicator of training in the wide sense. 
Table 24. Participation in training (in the narrow sense) by the potential labour force between the ages of 15 and 49

\begin{tabular}{lrrrrr}
\hline & $\begin{array}{c}1983 \\
\%\end{array}$ & $\begin{array}{c}1984 \\
\%\end{array}$ & $\begin{array}{c}1985 \\
\%\end{array}$ & $\begin{array}{c}1986 \\
\%\end{array}$ & $\begin{array}{c}1987 \\
\%\end{array}$ \\
\hline West Germany & -- & 5 & 7 & 8 & 8 \\
The Netherlands & 5 & -- & 5 & -- & 6 \\
United Kingdom & 7 & 7 & 7 & 7 & 8 \\
Denmark & -- & 13 & 15 & 16 & 16 \\
Greece & 1 & 1 & 1 & 1 & 1 \\
Belgium & 2 & 2 & 2 & 2 & 2 \\
Luxemburg & 3 & 3 & 3 & 3 & 3 \\
Ireland & 3 & 3 & 3 & 3 & 3 \\
Italy & 1 & 1 & 1 & 1 & 2 \\
& & & & & \\
\hline
\end{tabular}

Source : Eurostat/ROA

Legend : -- = not available

Strikingly, training participation is relatively low in West Germany, a country noted for its well-developed initial dual education.

The participation indicators permit a comparison with other countries, but only, for the time being, with other member states of the European Community.

\subsubsection{Training agreements in Collective_Employment Contracts}

This section presents an indicator of the training agreements included in collective employment contracts. This indicator expresses the number of employed coming under the regime of collective employment contracts with training agreements as a percentage of the total number of employed coming under collective employment contracts. Training agreements 15 (usually several in each collective employment contract) can be divided into seven categories:

1. Plans and intentions, for instance an inventory of the need for training, or a study to draw up a youth employment scheme;

2. Introduction or modification of a training programme or youth employment schemes, often including apprenticeships;

15. The Collective Labour Conditions Service's annual inquiries into collective employment contracts include apprenticeships in the notion of "training". 
3. Experimental jobs for schoolleavers and/or unemployed;

4. Associations of (regional) employers to train new entrants, sometimes combined with pooling;

5. Regional experiments for the training and employment of unemployed skilled builders;

6. Reservation of money from corporate training funds and sectoral training and development funds for new training activities or the intensification of existing ones, to be paid for out of (raised) contributions from the companies involved, to be set in relation to their wage sums;

7. Training agreements relating worktime to training. Two types can be distinguished: agreements with respect to the proportion of the employee's annual worktime to be spent on training, and agreements about the employee's claim to annual days off for training purposes.

The first five categories mostly refer to specific target groups, often schoolleavers and/or long-term unemployed.

Training efforts are indicative of the scientific and technological infrastructure, in particular the degree to which working people (can) respond to the diffusion of technological progress. The Collective Employment Conditions Department of the Ministry of Social Affairs and Employment ('DCA') annually surveys and publishes the results of the negotiations about collective employment contracts. However, the survey reports only mention the collective employment contracts negotiated in the calendar year in question. For a review of all collective employment contracts applicable at a given point in time, several annual surveys have to be combined. That is indeed the approach we have followed.

With respect to the market sector only the large collective employment agreements have been investigated, that is, those applicable to 5,000 or more employed persons. In the 1985-7 period, these large contracts covered 87 per cent of the total number of collective-contract employed in the market sector 16 .

16. For the subsidised sector only those general collective contracts are investigated that come under the Temporary Collective Sector Employment Conditions Act or the Act on the Development of Employment Conditions for the Subsidised Sector. 
Plans and intentions included in collective employment contracts have been left out of consideration in calculating the indicators, because they may take long to realise and may even not be realised at all.

The training expenditure incorporated in collective employment contracts can be computed in a narrow and a wide sense. To start with the former: the narrow concept implies that only the agreements laid down in collective employment contracts about sectoral funds set aside wholly or in part for training purposes are considered. The indicator computed on that basis expresses the number of employed coming under the regime of collective contracts incorporating funds set aside wholly or in part for training, as a percentage of the total number of employed coming under a collective contract. Mark that the existence of a sectoral fund is no guarantee that its financial means will actually be spent on training. One reason why the money does not get spent may be that the training positions created prove hard to fulfil. Another possibility is that agreements made on the level of sectors are insufficiently implemented on the company level.

Table 25. Percentage of employed coming under collective employment contracts carrying agreements about training funds (end of 1980 to 1987)

\begin{tabular}{lc}
\hline Year & $\begin{array}{c}\text { Indicator } \\
\%\end{array}$ \\
\hline 1980 & 10 \\
1981 & 31 \\
1982 & 26 \\
1983 & 37 \\
1984 & 38 \\
1985 & 36 \\
1986 & 36 \\
1987 & 37
\end{tabular}

Source : DCA/ROA

Table 25 traces the development of the indicator in the narrow sense in the 1980-87 period. The indicator has been computed from data in the annual survey reports of the Collective Employment Conditions Department.

A striking feature is the tremendous rise of the indicator in 1981, when a great number of very large collective employment contracts for the first time included the stipulation that the existing sectoral fund (often called 'Development Fund') was to be reserved in part for the training of, in 
principle, all employed persons 17 . Since 1983, about 37 per cent of collective-contract employed in the Netherlands come under sectoral funds which are (also) reserved for training. Actually, of late years some funds have been created for the express purpose of training and education. Moreover, some existing general funds have been converted into specific training funds; because the collective contracts involved were mostly small, the effect on the index has been slight.

The indicator in the wide sense expresses the number of employed coming under the regime of collective contracts carrying training agreements in a percentage of the total number of employed under collective employment contracts. To calculate the comprehensive indicator, use has been made of an investigation carried out by the Collective Contract Department in 1984 into the way collective contracts lay down measures to stimulate the education and training of employed persons. The reference time of this single investigation 18 was the end of August 1984. Contracts that had expired before the first of January 1984 and not been renewed with the Department on the reference date, were left out of the investigation. Thus, the research referred to collective contracts applicable during the 1983-84 or the 1984-85 period (one-year contracts) or the 1984-1985 period (two-year contracts) 19 .

In the report quoted above, the stipulations about training are classified according to the category of employed people to which they apply. The result was the following division:

- stipulations applicable to all employed persons;

- stipulations referring only to young persons;

- pre-retirement courses for senior staff;

- trade-union courses for union members and courses for members of works councils.

17. Previously, these contracts often stipulated as one purpose of the fund the training of employees' representatives a function in works councils.

18. Collective Employment Conditions Department, Educatie in CAO's, The Hague, 1985.

19. All collective employment contracts for companies employing 2,000 or more workers (22 contracts) and a sample of 38 sectoral collective contracts were investigated. The two categories investigated cover 201,000 and 1,621,000 employed, respectively. 
Pre-retirement courses, trade-union courses and courses for members of works councils serve other purposes than the proper response to technological progress. Therefore, these courses, as well as statements of intention, recommendations and such, will be left out of the calculation of the indicator in the wider sense. So will agreements in collective contracts about experimental positions for schoolleavers and/or unemployed persons chiefly intended to improve the chances of those groups on the labour market by the temporary stimulation of employment.

In 1984, 96 per cent of the surveyed collective-contract employees in the Netherlands came under a collective employment contract holding training stipulations applicable to all workers included in the contract; 87 per cent of the employed came under a collective contract laying down rules about the training of young people.

For other years, an indicator of training in the wider sense can only be put together from information about separate collective employment contracts. Obviously, to consult all individual collective contracts would fall outside the scope of the present investigation, and has therefore not been attempted.

Similar to the indicator of training expenditure, the indicator of training agreements in collective contracts cannot be compared internationally for lack of data sources from international organisations. A comparison would anyhow be difficult in view of the variations in coverage and character of collective contracts in different countries. 


\section{EVALUATION}

In this final chapter we will first sum up how the indicators described in chapter 2 would rank in a databank of technology indicators. Next, the indicators discussed in chapter 2 will be briefly evaluated by the two criteria mentioned earlier, namely: international comparability and continuity of data sources.

\subsection{Summarising review}

Figure VIII recapitulates how the indicators presented in the preceding chapter would in principle be placed in a data bank for technology indicators. To that end, the indicators have been considered under two aspects. First, their relevance to initial education, the degree of education of the labour force, the need for training, and the training efforts. Second, the extent to which they are indicative of the scientific and technological infrastructure for the creation and/or diffusion of technological innovations. We present the recapitulation without further comment, but referring to the discussion of the indicators in chapter 2.

\subsection{Suitability test}

To be viable, an indicator must satisfy the criteria of international comparability and continuity of data sources. An indicator that cannot be composed every year or every other year and for which internationally comparable data are lacking can hardly make a meaningful contribution to a data bank for technology indicators. Indicators that can be calculated every year or every other year and are also internationally comparable, on the other hand, are eminently suitable for a databank. Evidently these are two extremes; there are also indicators which occupy an intermediate position.

In the matrix of figure IX below, indicators are positioned according to the degree to which they satisfy the two criteria mentioned. An indicator in the top left-hand side is hardly viable, while one in the bottom right-hand corner is eminently suitable for inclusion in a databank. In a brief discussion of the completed cells of the matrix from top left to bottom right, the significance of the indicator's position for the functioning of the data bank of technology indicators will be indicated. 
FIGURE VIII: SUMMARIZING REVIEW TECHNOLOGY INDICATORS EDUCATION AND LABOUR MARKET

\begin{tabular}{|c|c|c|}
\hline & DIFFUSION POTENTIAL & INNOVATION- AND DIFFUSION \\
\hline INITIAL EDUCATION & $\begin{array}{l}\text { - TRAINEES FOLLOWING } \\
\text { DUAL EDUCATION }\end{array}$ & $\begin{array}{l}\text { - EDUCATIONAL EXPENDITURE } \\
\text { PER STUDENT } \\
\text { - SHARE OF VOCATIONAL } \\
\text { EDUCATION IN TOTAL REGULAR } \\
\text { EDUCATION } \\
\text { - SHARE OF GRADUATES WITH A } \\
\text { TECHNICAL EDUCATION IN THE } \\
\text { TOTAL NUMBER OF GRADUATES } \\
\text { OF HIGHER EDUCATION } \\
\text { - COMPUTERS IN PRIMARY AND } \\
\text { SECONDARY EDUCATION }\end{array}$ \\
\hline $\begin{array}{l}\text { LABOUR FORCE } \\
\text { AND } \\
\text { SCHOOLLEAVERS }\end{array}$ & & $\begin{array}{l}\text { - AVERAGE LEVEL OF EDUCATION } \\
\text { OF SCHOOLLEAVERS AND THE } \\
\text { POTENTIAL LABOUR FORCE } \\
\text { - SHARE OF TECHNICALLY } \\
\text { EDUCATED IN THE TOTAL } \\
\text { NUMBER OF SCHOOLLEAVERS } \\
\text { AND IN THE POTENTIAL } \\
\text { LABOUR FORCE } \\
\text { - SHARE OF TECHNICALLY } \\
\text { EDUCATED IN MANAGEMENT } \\
\text { OCCUPATIONS }\end{array}$ \\
\hline NEED FOR TRAINING & $\begin{array}{l}\text { - TENSIONS IN THE LABOUR } \\
\text { MARKET SITUATION OF } \\
\text { TECHNICALLY TRAINED } \\
\text { PEOPLE } \\
\text { - SHARE OF OVER THIRTIES } \\
\text { PERSONS IN THE } \\
\text { ECONOMICALLY ACTIVE } \\
\text { POPULATION }\end{array}$ & \\
\hline TRAINING EFFORTS & $\begin{array}{l}\text { - TRAINING EXPENDITURE } \\
\text { - PROPORTION OF THE } \\
\text { POTENTIAL LABOUR FORCE } \\
\text { PARTICIPATING IN } \\
\text { TRAINING } \\
\text { - TRAINING AGREEMENTS IN } \\
\text { COLLECTIVE EMPLOYMENT } \\
\text { CONTRACTS }\end{array}$ & \\
\hline
\end{tabular}


1. Continuous data sources are lacking and the indicator is not internationally comparable. The indicator of training agreements in collective employment contracts in the wide sense comes under this heading. This indicator can be calculated only for the Netherlands, and that only on the basis of a single investigation. Its contribution to the databank is accordingly small.

2. The continuity of the data sources is uncertain and the indicator is not yet internationally comparable. The indicator of training expenditure, composed from a CBS publication, belongs to this category. The CBS has not yet decided to publish the relevant data periodically, nor are international comparable data on training expenditure available as yet. Easily comparable international data are not expected to come available shortly, given the problems involved in the uniform definition of training efforts. Therefore this indicator, like the previous one, will contribute little to the databank.

3. Internationally comparable indicators will become feasible in the future, but the continuity of the sources is uncertain. This category contains one indicator, namely, the number of computers in primary and secondary education. The International Association for the Evaluation of Educational Achievement organised a survey in 1989 in which one question referred to the number of computers in schools. This survey will be repeated in 1992. There are no plans as yet for periodical surveys. Therefore, the contribution of the indicator to the databank is limited for the time being.

4. Continuous data sources are available, but international comparisons are not yet possible. This category consists of six indicators, namely: the average educational level of schoolleavers, the share of technically trained persons in the total number of schoolleavers and in the labour force, the proportion of technicians in management occupations, indicators of tension on the labour market of technicians, and training agreements in collective employment contracts in the wide sense. In the Netherlands these indicators can be composed annually or once every other year. An inquiry would have to be held to establish whether other national statistical offices do have relevant internal information on this point. If so, these indicators would be very useful for a databank for technology indicators. 
5. Continuous data files are available and internationally comparable indicators come within reach in the future. Only the average level of education of the potential labour force comes within this category. From 1988 onward, the Labour Force Survey of the European Community has contained a question after the population's highest completed education. From that information, the average level of education of the potential labour force can be established. In the near future this indicator can make a meaningful contribution to the databank of technology indicators.

6. Continuous data files are available and international comparisons are possible. Six indicators can be counted to this category, namely: educational expense per student, share of vocational education in total regular education, number of trainees following dual education, share of graduates with technical training in the total number of graduates of higher education, share of over-thirties persons in the economically active population, and the proportion of the potential labour force following training courses. These indicators are instantly usable for a databank. For some indicators the comparability is limited to member states of the European Community.

The conclusion is that on the whole the continuous supply of the proposed indicators is within reach. The problem is, however, that quite a few indicators come available with considerable delay. Admittedly, for the indicators referring to the number of technicians in management functions the delay is merely due to the initial difficulties the CBS is experiencing in processing the Labour Force Survey held for the first time in 1987. The expectation is warranted that in future the data will be supplied more promptly. For indicators collected by international organisations a prolonged delay is usual. As far as this delay is related to the time involved in the publication of Yearbooks, time could be saved if the data could also be consulted interactively in automated data banks. Perhaps initiatives to that effect could be taken.

Strikingly, publications of the European Community and the OECD (as well as the CERI) are paying little attention to the level of education of the labour force, in spite of the lively and increasing international interest that has been manifest for some time. Again, initiatives towards a more adequate data supply would be useful. Another striking aspect is the strong emphasis these two international organisations 


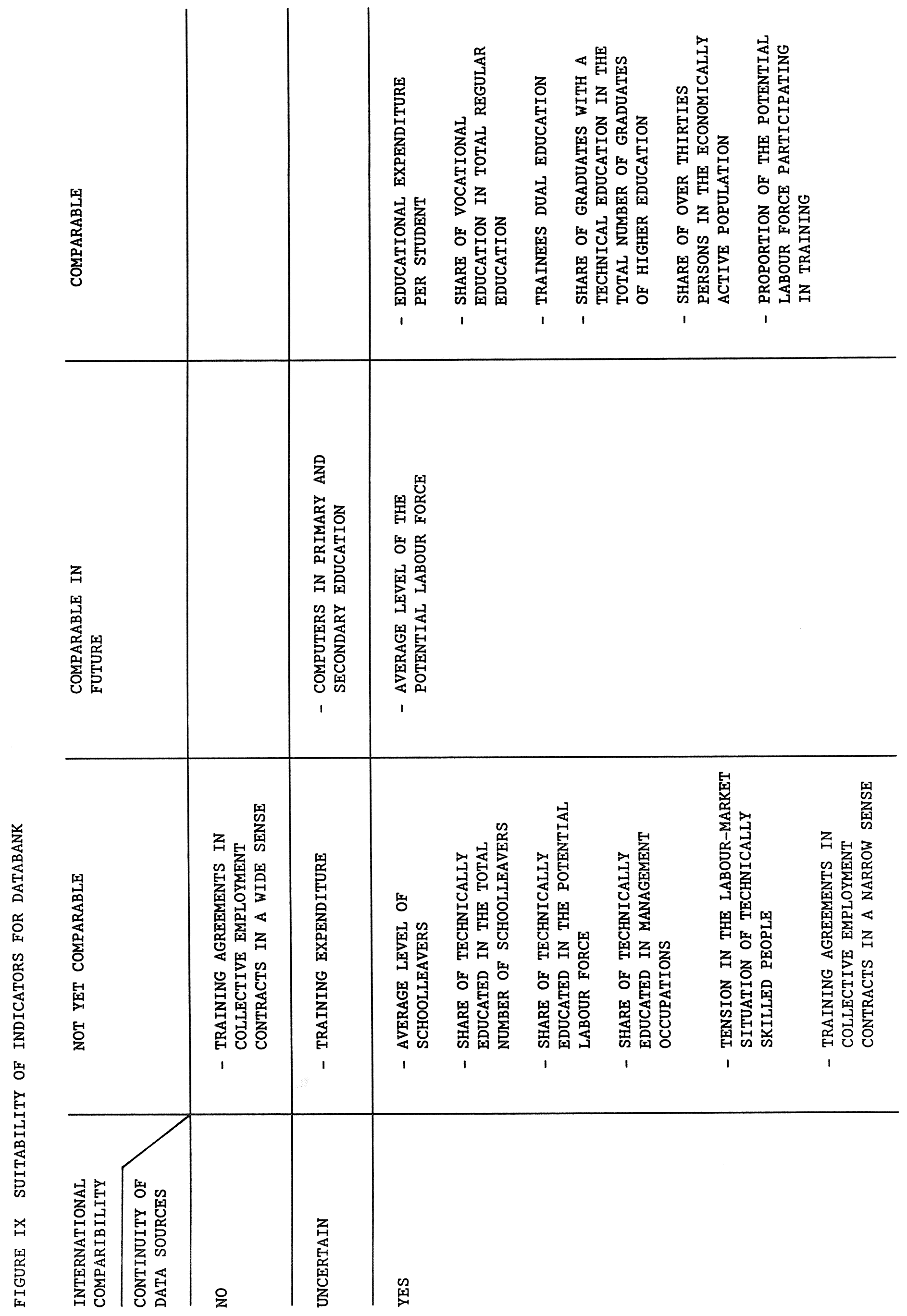


$-43-$

are putting on so-called 'historical data'. It would be useful also to include the demographic and (socio-)economic forecasts made in the various countries in an international databank. 


\section{LITERATURE}

Brumelhuis, A. (1989), Invoering van computers vraagt van docenten veel tijd, in: Didactief, februari 1989, pp. 23-25.

Centraal Bureau voor de Statistiek (1988), Bedrijfsopleidingen in Nederland 1986, Staatsuitgeverij, 's Gravenhage.

Centraal Planbureau (1989), Tijdreeksen uit de onderwijsprognose 1989, 's Gravenhage.

Europese Gemeenschap Eurostat (1988), Labour Force Survey Methods and Definitions 1988, Luxembourg.

Europese Gemeenschap Eurostat (1989), Labour Force Survey (niet gepubliceerde statistieken), Luxembourg.

Grip, A. de, J.A.M. Heijke (1988), Arbeidsmarktindicatoren: een inventarisatie, ROA-W-1988/1, Maastricht.

International Labour Organization (1982, 1983, 1984, 1985, 1986, 1987 , 1988), Yearbook of Labour Statistics, Geneva.

Kodama, F., F. Niwa (1987), Structure Analysis of the Japanese Science Indicator System and Its Evaluation, in: The Journal of Science Policy and Research Management, Vo1.2, no 2, pp. 173-183.

Ministerie van Economische Zaken, (1988), METING Voorstel voor een gegevensbank van Technologie Indicatoren voor A.T.B., 's Gravenhage.

Ministerie van Onderwijs en Wetenschappen. Inspectie Basisonderwijs, Inspectie Speciaal en Voortgezet Speciaal Onderwijs (1986), Onderwijs en Informatietechnologie. Een beschrijving van de stand van zaken in het schooljaar 1985/1986. Verslag van een inspectie-onderzoek in het basisonderwijs, speciaal onderwijs en voortgezet speciaal onderwijs. Inspectierapport 9, 's-Gravenhage.

Ministerie van Onderwijs en Wetenschappen. Inspectie Lager Beroepsonderwijs, Inspectie Algemeen Voortgezet Onderwijs en Voorbereidend Wetenschappelijk Onderwijs (1987), Onderwijs en Informatietechnologie. Een beschrijving van de stand van zaken in het schooljaar 1985/1986. Verslag van een inspectie-onderzoek in het lager beroepsonderwijs, algemeen voortgezet en voorbereidend wetenschappelijk onderwijs. Inspectierapport 12, 's-Gravenhage.

Ministerie van Onderwijs en Wetenschappen. Inspectie Voortgezet Onderwijs/Beroeps Onderwijs (1987), Onderwijs en Informatietechnologie. Een beschrijving van de stand van zaken in het schooljaar 1986/1987. Verslag van een inspectie-onderzoek in het middelbaar technisch onderwijs en het middelbaar nautisch onderwijs. Inspectierapport 21, 'sGravenhage.

Ministerie van Onderwijs en Wetenschappen. Inspectie Voortgezet Onderwijs/Beroeps Onderwijs (1988), Onderwijs en Informatietechnologie. Een beschrijving van de stand van zaken in het schooljaar 1986/1987. Verslag van een inspectie-onderzoek in het middelbaar economisch en administratief onderwijs, het middelbaar middenstandsonderwijs en het middelbaar horeca-onderwijs. Inspectierapport 24, 's-Gravenhage. 
Ministerie van Onderwijs en Wetenschappen (1989), Verstrekking van computers in COMENIUS-project, in: Uitleg, juni 1989, pp. 12-13.

Ministerie van Sociale Zaken en Volksgezondheid. Loonbureau (1979 - 1981), CAO's in Nederland. Een systematische samenvatting van lonen en andere arbeidsvoorwaarden in Nederland, vastgelegd in collectieve arbeidsovereenkomsten en bindende regelingen, Staatsuitgeverij, 's-Gravenhage.

Ministerie van Sociale Zaken en Werkgelegenheid. Dienst Collectieve Arbeidsvoorwaarden (1982 - 1987), CAO's in Nederland. Een systematische samenvatting van lonen en andere arbeidsvoorwaarden in Nederland, vastgelegd in collectieve arbeidsovereenkomsten (en bindende regelingen), Staatsuitgeverij, 's-Gravenhage.

Ministerie van Sociale Zaken en Werkgelegenheid. Dienst Collectieve Arbeidsvoorwaarden (1985), Educatie in CAO's. Deel I en II, Staatsuitgeverij, 's-Gravenhage.

Moonen, J. (1986), Toepassing van computersystemen in het onderwijs, Staatsuitgeverij, 's-Gravenhage.

Paridon, W.C.G.M. van (1987), De arbeidsmarktindicator, in: Management Berichten, jrg. 13, $\mathrm{nr} .3, \mathrm{p} .42-46$.

Svergisges officiella statistik Statistiska centralbyrån (1985), Befolkningens och arbetskraftens utbildningsnivå, Enligt arbetskraftsundersökninggarna 1971-1978, in: Statistiska Meddelanden, Am 14 SM 8501.

Unesco (1984, 1985, 1986, 1987), Unesco Statistical Digest, Paris.

Unesco (1984, 1985, 1986, 1987, 1988), Unesco Statistical Yearbook, Paris. 
Table 11. Indicator of the average educational level of schoolleavers in comparison with the potential labour force.

\begin{tabular}{|c|c|c|}
\hline & $\begin{array}{c}\text { indicator technical } \\
\text { education }\end{array}$ & $\begin{array}{c}\text { indicator total } \\
\text { education }\end{array}$ \\
\hline $\begin{array}{l}1982 / 83 \\
1983 / 84 \\
1984 / 85 \\
1985 / 86 \\
1986 / 87 \\
1987 / 88 \\
1988 / 89 \\
1989 / 90 \\
1990 / 91 \\
1995 / 96 \\
2000 / 01\end{array}$ & $\begin{array}{l}100 \\
100 \\
101 \\
102 \\
104 \\
108 \\
109 \\
108 \\
108 \\
109 \\
107\end{array}$ & $\begin{array}{l}111 \\
110 \\
110 \\
109 \\
110 \\
112 \\
113 \\
111 \\
111 \\
109 \\
104\end{array}$ \\
\hline
\end{tabular}

Source : $\mathrm{CPB} / \mathrm{ROA}$

1) Percentage relation between the level of education of the technically educated among schoolleavers and the average level of education of the technically educated in the potential labour force.

2) Percentage relation between the level of education of schoolleavers and the average level of education of the potential labour force.

Figure II Indicator of the average level of education of schoolleavers in comparison with the potential labour force

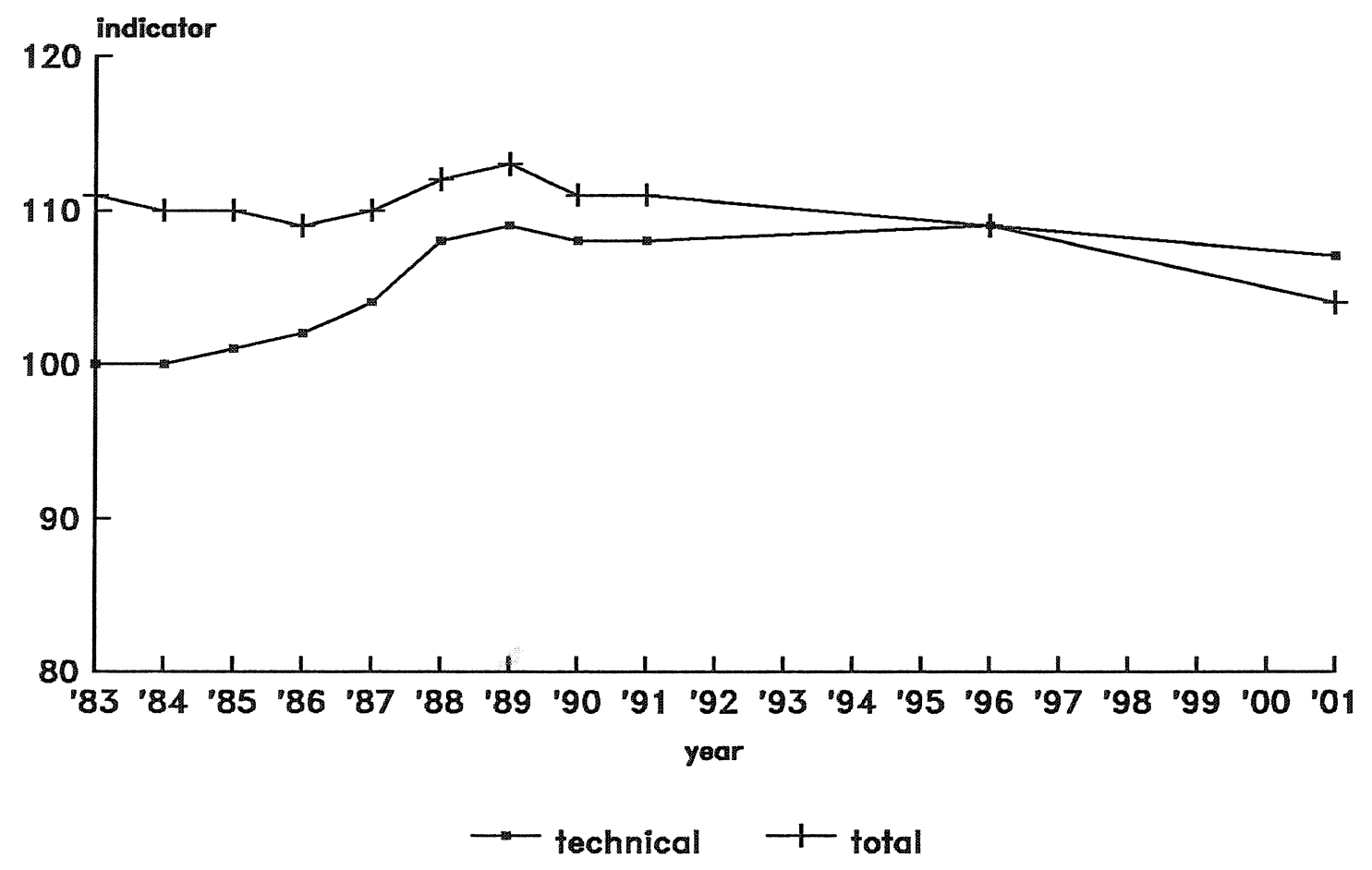

Source: $C P B / R O A$ 
Table 10. Average level of education of schoolleavers*

\begin{tabular}{lcc}
\hline & $\begin{array}{c}\text { technically educated } \\
1 \text { ) }\end{array}$ & total labour force \\
2)
\end{tabular}

Source : $\mathrm{CPB} / \mathrm{ROA}$

* There are no comparable data for the years 1980 and 1981.

1. Average level of education of schoolleavers from technical schools.

2. Average level of education of schoolleavers from the entire educational system.

Figure I Average level of education of schoolleavers

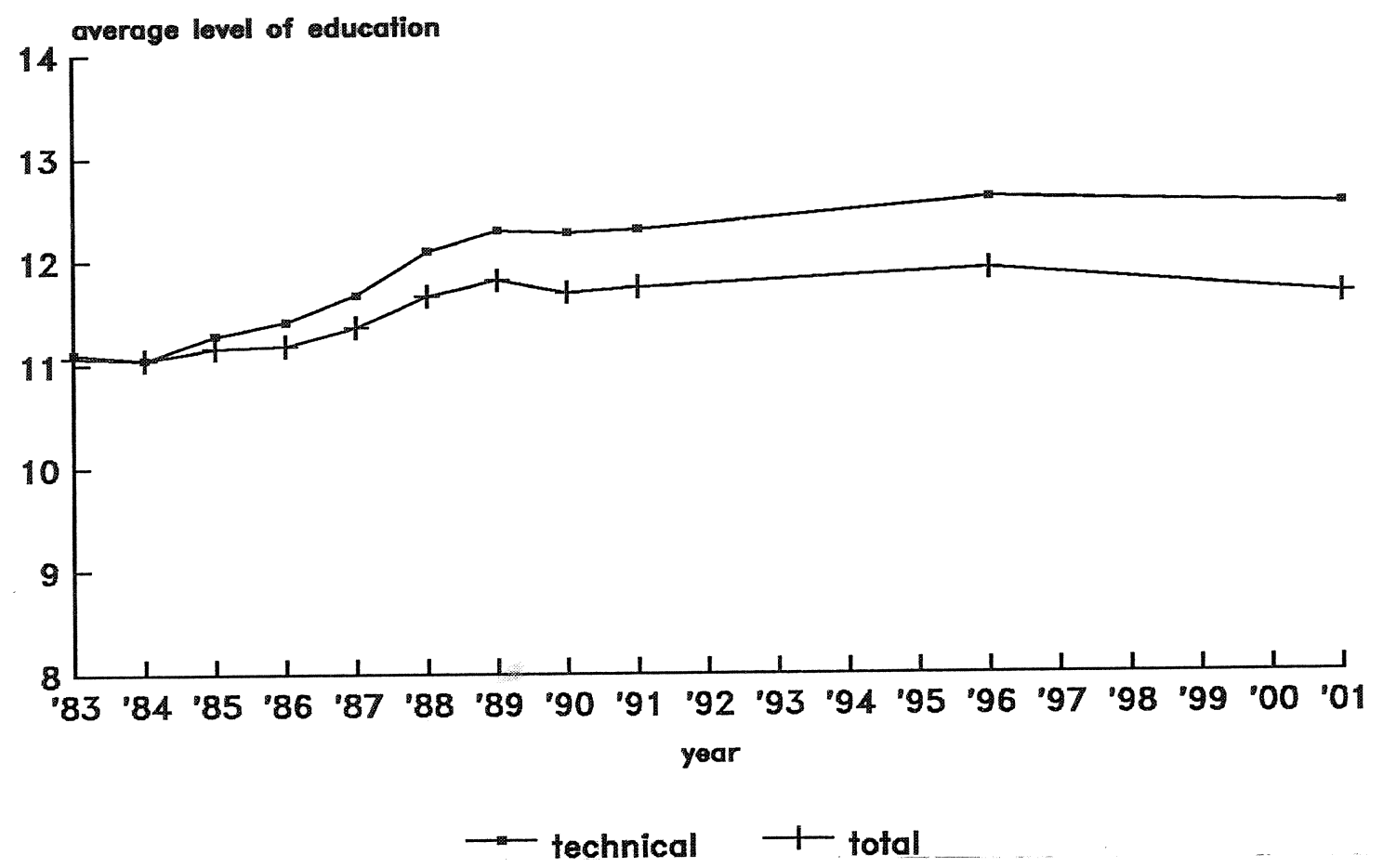

Source : $\mathrm{CPB} / \mathrm{ROA}$ 
Figure III Indicator of the share of (higher) technically educated

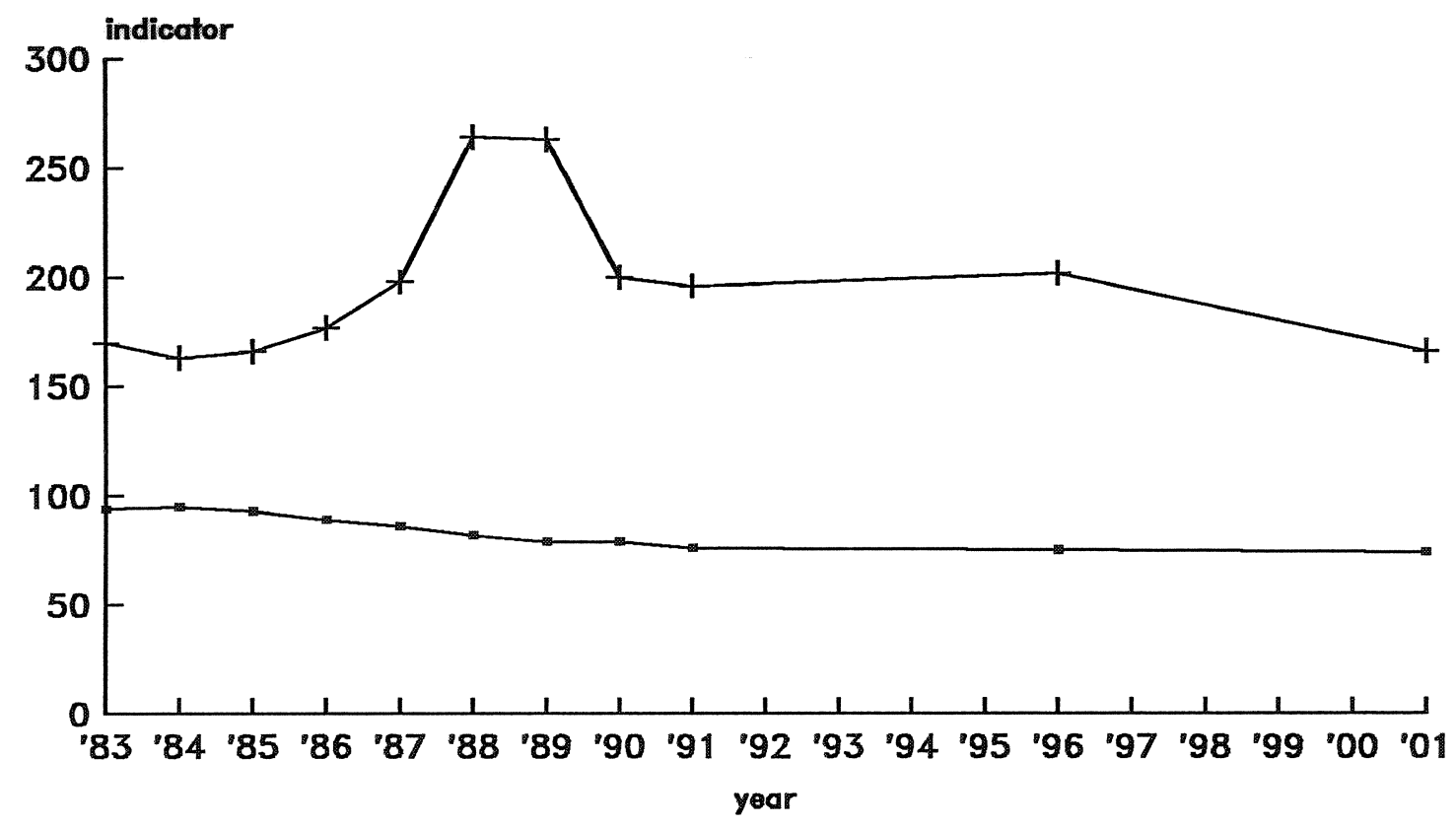

$\longrightarrow$ total + higher

Source: $C P B / R O A$

Figure IV Share of technically educated

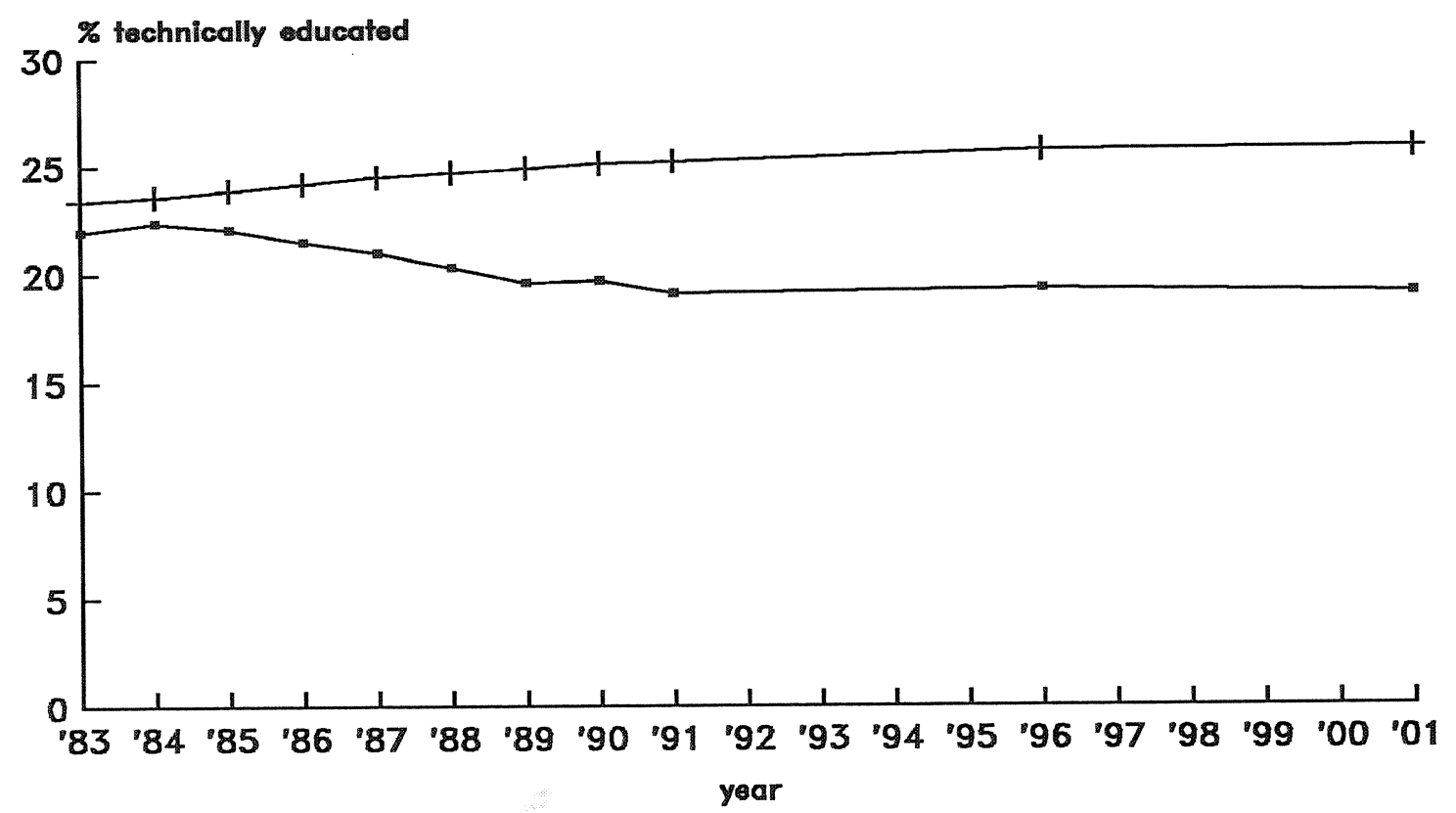

- schoolleavers 1 potent. labour force 
Figure $V$ Share of higher educated technicians

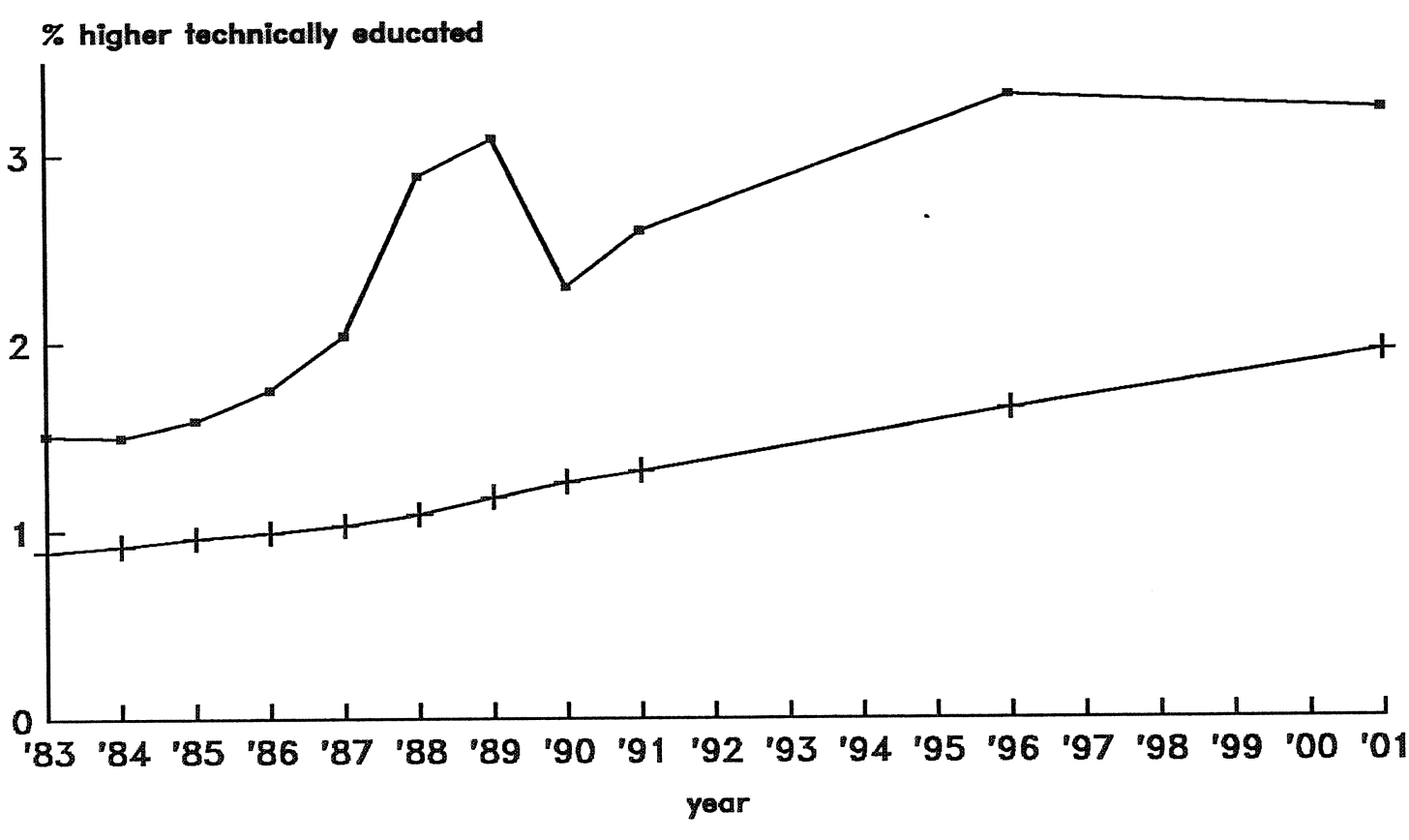

$\longrightarrow$ schoolleavers + potent. labour force

Source : CPB/ROA

\subsubsection{Share of technically educated in management_occupat_ations}

The indicator to be presented here concerns the share of the technically educated in management occupations. The MEASUREMENT paper describes it as indicative of the societal infrastructure for technological developments. A more accurate expresion would be 'indicative of the scientific and technological infrastructure. The indicator represents the technological perceptiveness of corporate management. It could be regarded as indicative of the scientific or technological infrastructure for both the introduction of technological innovations (the innovative potential) and the diffusion of technological developments (the diffusion potential).

For the Netherlands, the share of technically educated in management occupations can be computed from data deriving from the Labour Force Censuses. These were conducted once every two years by the CBS up to 1987, when they were replaced with the Labour Force Survey. The labour-force censuses classifies schools by codes of the Standard Education Classification (more or les equivalent with ISCED), and distinguished the following types of technical education: 
Figure VI Share of technically educated in management occupations

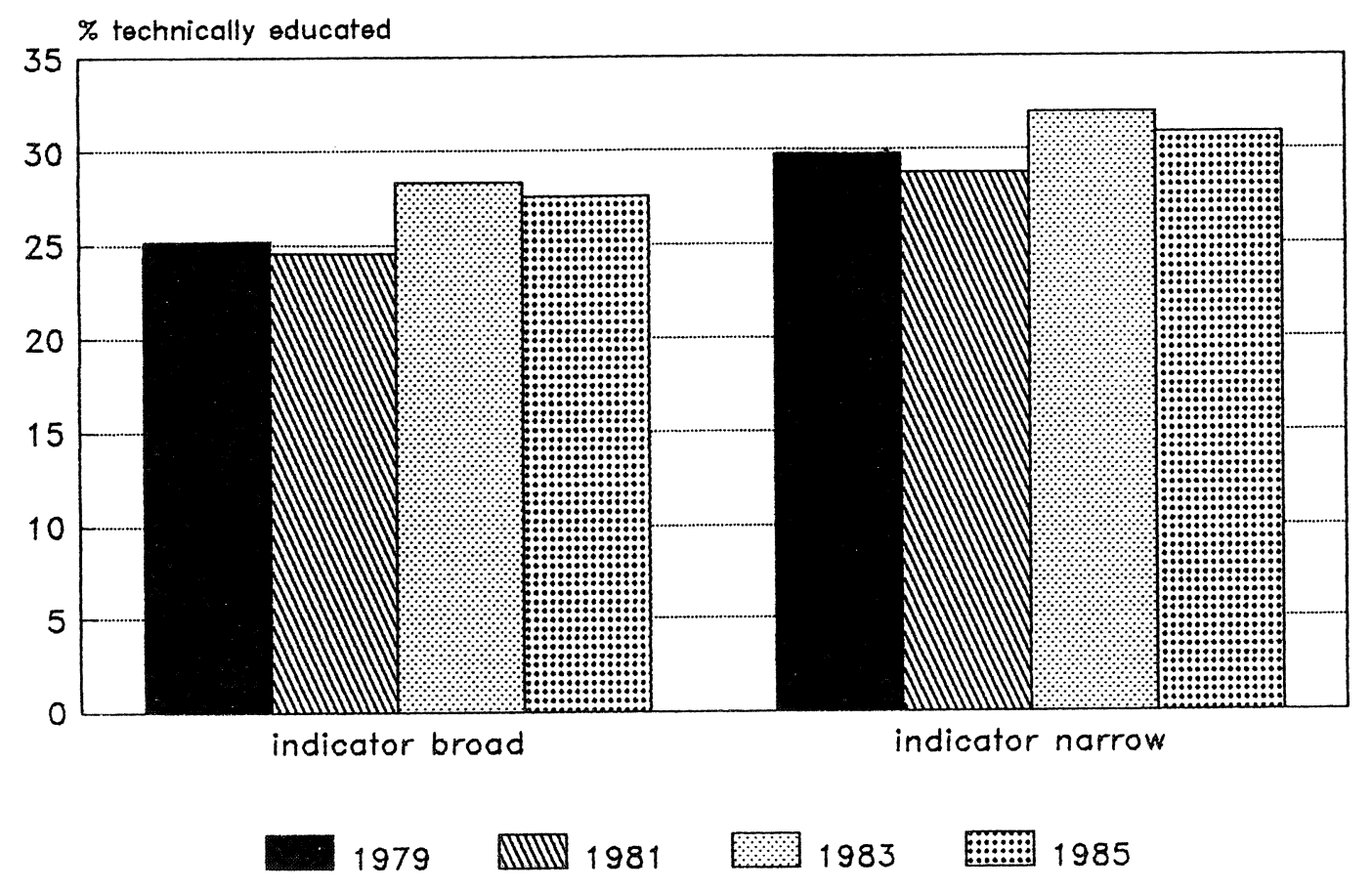

Source : CBS/ROA

Table 15 shows a slight increase in the share of technically educated in management occupations in the broad sense between 1981 and 1983, which did not persist beyond that period. The series representing the number of technically educated in managerial occupations in the narrow sense shows a similar pattern on a higher level.

Next, the share of higher educated technicians (Higher Vocational Education and University education) in management occupations was established, again in the broad and narrow senses.

Table 16. Share of higher educated technicians in management occupations

\begin{tabular}{lcc}
\hline & broad indicator & narrow indicator \\
$\%$ & $\%$ \\
\hline & 9.3 & 12.0 \\
1979 & 8.7 & 11.1 \\
1983 & 9.8 & 11.7 \\
1985 & 9.0 & 10.8 \\
\hline
\end{tabular}


Figure VII Share of higher educated technicians in management occupations

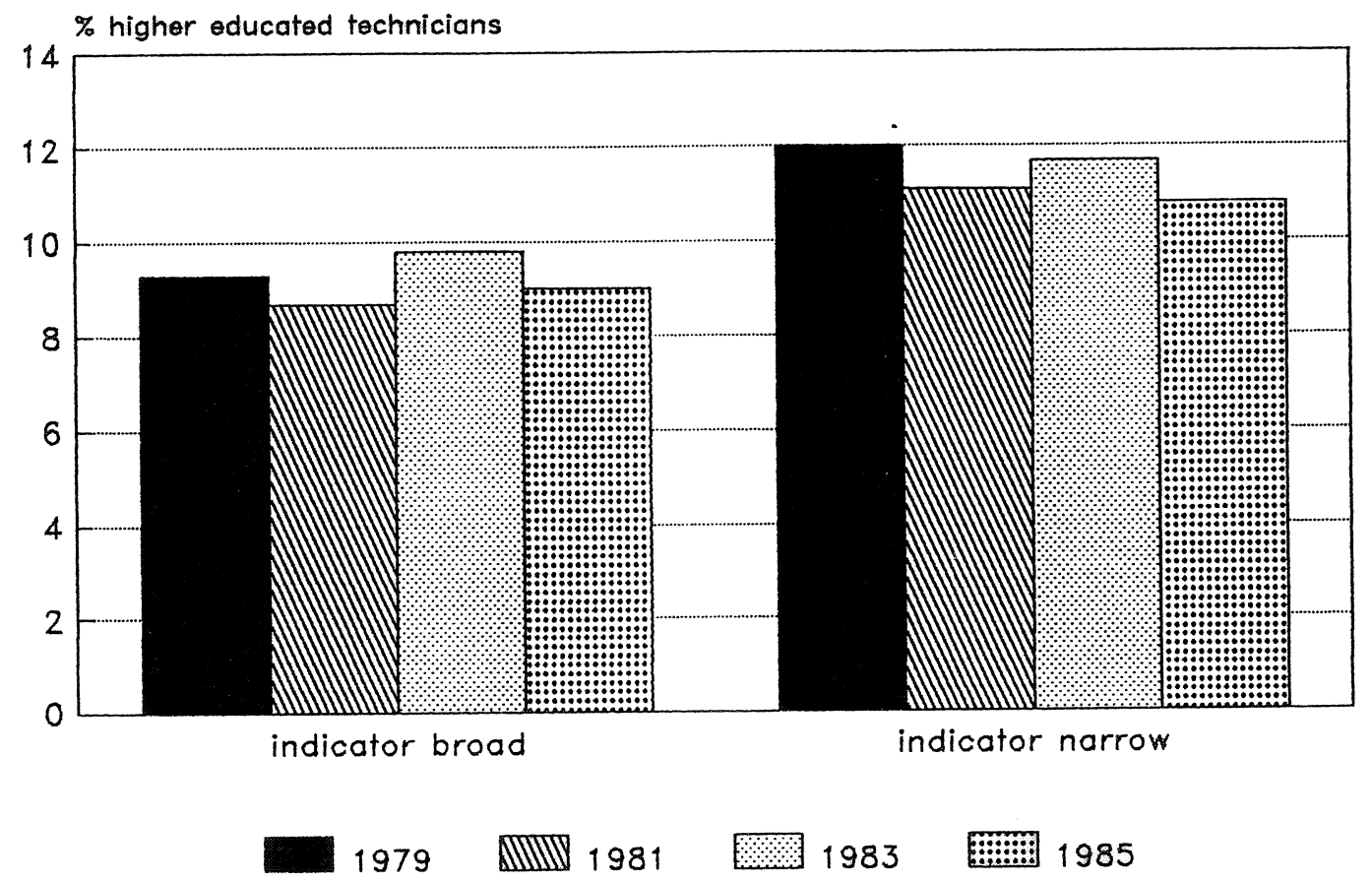

Source : CBS/ROA

The proportion of higher educated technicians in management occupations in the broad sense fell slightly in the 1979-1985 period. The same pattern prevails for the narrow indicator, again, as could be expected, on a higher plane.

Although there are no significant references between the development of time series of (higher) technically educated in management occupations in the narrow and the broad sense, we would plead the use of the 'narrow' indicator, in view of the insignificant proportion of technically educated persons in occupational classes 50 and 51.

In principle, the above indicators can also be derived from the LabourForce Surveys conducted since 1987. However, on account of teething troubles the CBS has not yet been able to publish educational data from that source. Nor are comparable data for other countries available. International organisations as Unesco, ILO, OECD or the European Community do not include them in their yearbooks, nor do they seem to have them available for internal use. Yearbooks and other publications of the various national statistical bureaus do not include these data. However, as these figures are also not published by the Dutch Bureau of Statistics, similar data might also be available internally with the other national statistical bureaus. 


\section{Fiquerb}

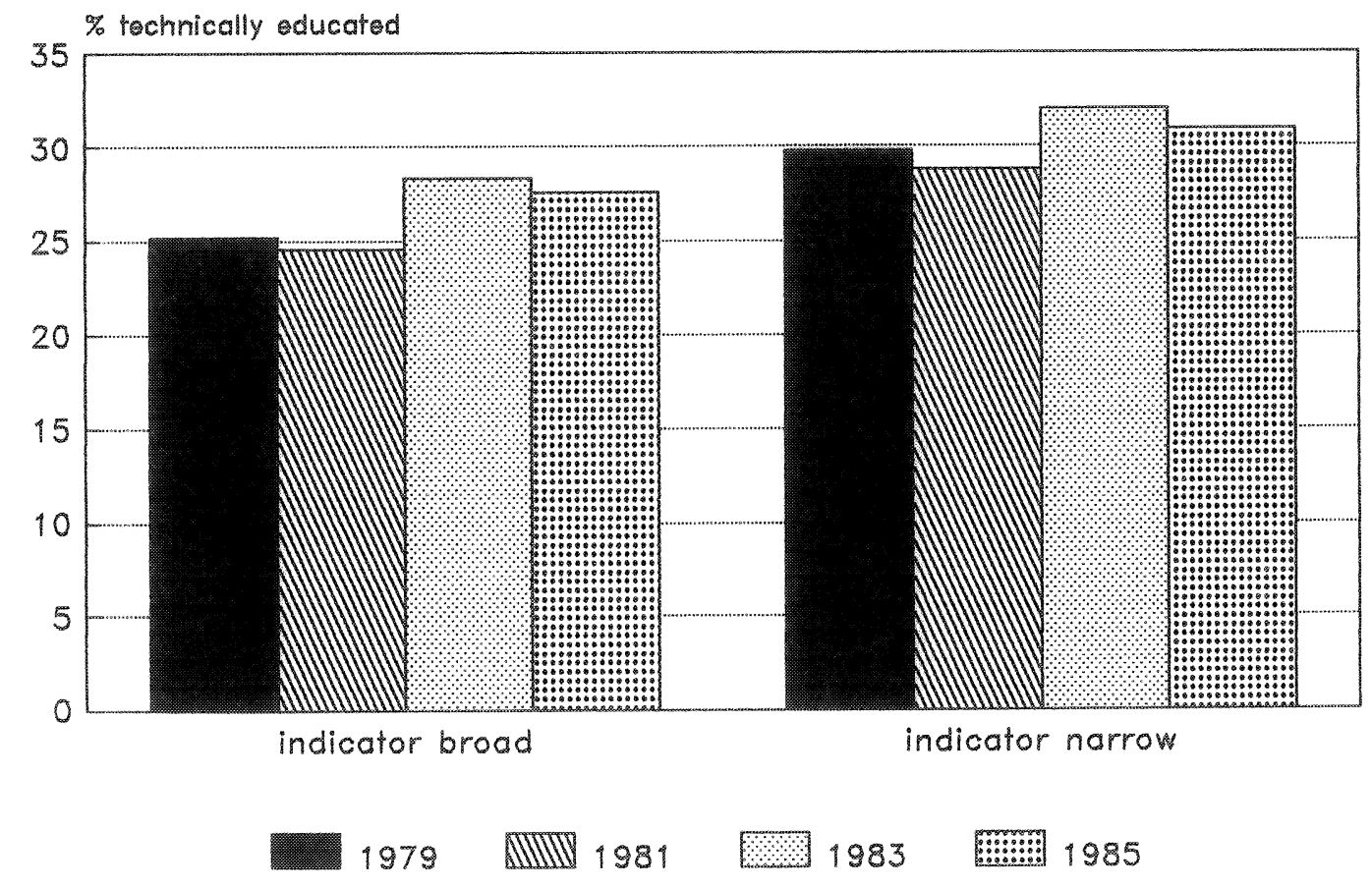


Figuer 7

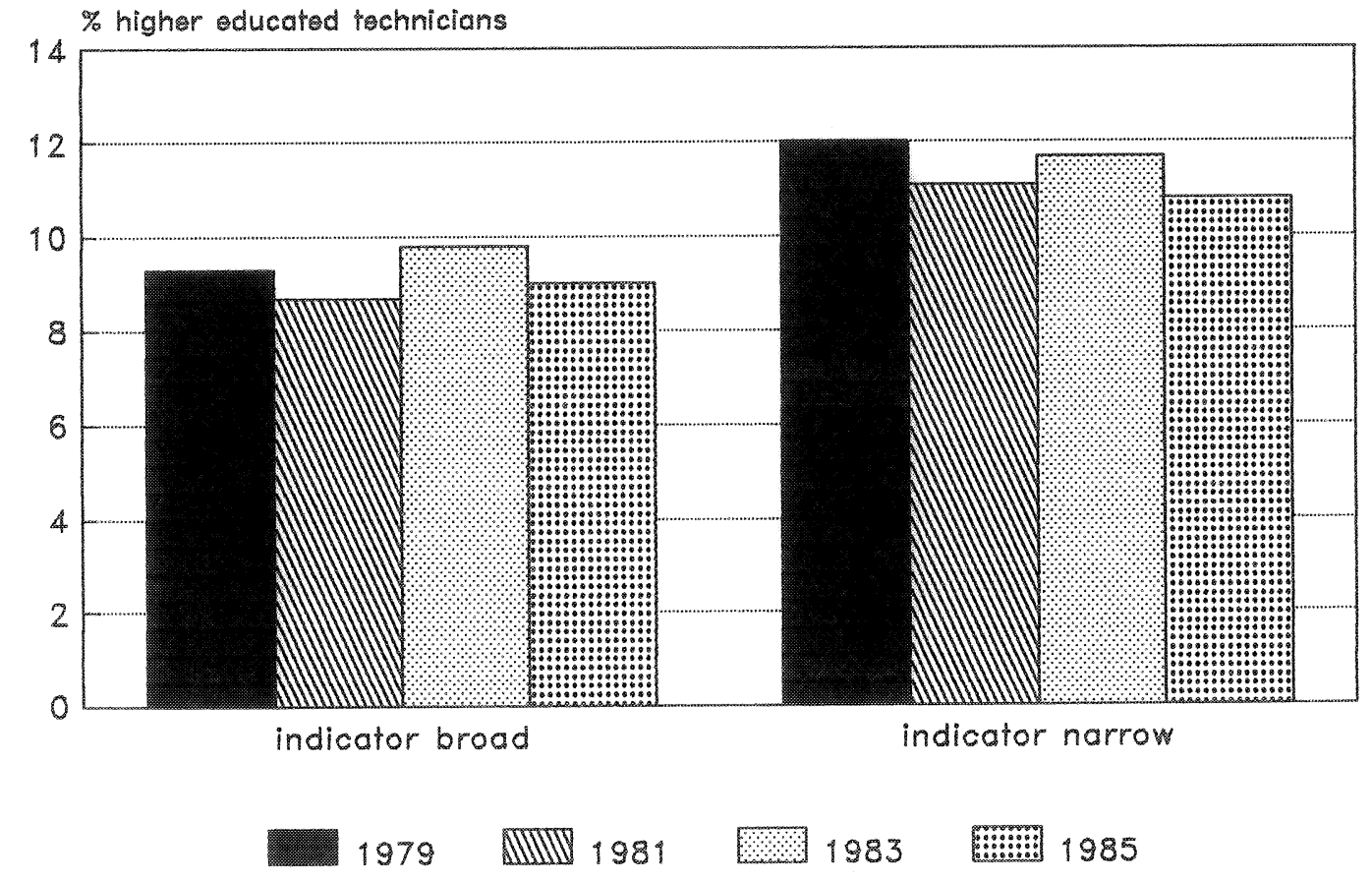

